\title{
21. Türk Lügatini farklı sözlük türleri ile karşılaştırma ve düzenleme denemesi
}

\section{Bekir SARIKAYA}

APA: Sarıkaya, B. (2021). Türk Lügatini farklı sözlük türleri ile karşılaştırma ve düzenleme denemesi. RumeliDE Dil ve Edebiyat Araştırmaları Dergisi, (24), 403-430. DOI: 10.29000/rumelide.990146.

\section{$\ddot{O}_{z}$}

Hüseyin Kazım Kadrî, Türk Lügatini geniş hacimli bir sözlük olarak hazırlamıştır. Kökenbilim, mukayese ve edebi örnekler içerir. Örneklerin edebi ve seçkin olması, başka sözlüklerde olmayan kelimelerin, deyimlerin, tanımların ve çeşitliliğin bulunması araştırmacılar tarafindan vurgulanan ve sözlüğün beğenilen özellikleridir. Öte yandan örneklerin dikkatsiz ve yanlış yazımı, bazı lehçelerle ilgili eksik ve yanlış bilgilerin bulunması, sözlük tekniği bakımından zayıf olması vb. durumlar sözlükbilimi açısından yerilmesine sebep olmuştur. Sözlük üzerine son zamanlarda çalışılmaya başlanmış, tezler yapılmıştır. Sözlüğün basımı 2010 yılında TDK’nin gündemine girmiş, fakat kayda değer bir sonuç çıkmamıştır. Geniş hacimli eserler önce doğru okunuşu/şekli ile ortaya konmalı, sözlükbilimi tekniği bilgisayar ortamında uygulanmalı ve sözlük kullanıcılarının isteğine göre de eser okuyucusuyla buluşmalıdır. Bu çalışmada Türk Lügatinden örnek olarak alınan kelimeler; genel sözlük, etimoloji sözlüğü, lehçebilim sözlüğü, deyim ve atasözleri sözlüğü vb. sözlüklerdeki kelimelerle madde başı ve iç madde yönünden karşılaştırılmıştır. Karşılaştırmada araştırmacıların sözlük üzerine yaptığı olumlu ve olumsuz tenkitler de dikkate alınmıştır. Sözlükbilimcilerin dikkati ve gayretiyle bu eserdeki eksiklerin giderilmesinin ve yanlışların düzeltilmesinin mümkün olduğu sonucuna ulaşılmıştır. Veritabanı geniş olan bu sözlüğün sözvarlığı, sözlükbilim tekniğine göre, farklı dizimler ile düzenlenip kullanıcıya sunulduğu takdirde, kolay kullanımlı bir sözlük ortaya konmuş olacaktır.

Anahtar kelimeler: Türk Lügati, sözlükbilimi, lehçe, sözcükbirim, dizgi deneme

\section{The comparison of Türk Lügati dictionary with different types of dictionaries and an attempt on its arrangement}

\begin{abstract}
Hüseyin Kazım Kadrî prepared the Türk Lügati as an extremely detailed dictionary. This dictionary contains etymology, comparison and literary examples. The existence of literary and distinguished examples, the presence of more diverse words, idioms and definitions than other dictionaries are the features of the dictionary that are emphasized and appreciated by researchers. On the other hand, features such as careless and inaccurate spelling of the examples, the presence of incomplete and incorrect information about some dialects and poor dictionary technique are the features that cause them to be criticized in terms of lexicology. Studies on the dictionary have been started recently and theses have been written. The publication of the dictionary has been included in the working plans of the TDK in 2010, but no significant results could be obtained. Large-volume works should be presented with the correct reading and form, the lexicography technique should be applied in the computer environment and should be presented with different printing forms according to the user
\end{abstract}

Doç. Dr., Afyon Kocatepe Üniversitesi, Fen Edebiyat Fakültesi, Türk Dili ve Edebiyatı Bölümü (Afyonkarahisar, Türkiye), bsarikaya67@hotmail.com, ORCID ID: oooo-0o02-9842-237X [Araştırma makalesi, Makale kayıt tarihi: 08.06.2021kabul tarihi: 20.09.2021; DOI: 10.29000/rumelide.990146]

Adres | Address

RumeliDE Dil ve Edebiyat Araşturmalar Dergisi $\quad$ RumeliDE Journal of Language and Literature Studies Osmanağa Mahallesi, Mürver Çiçeği Sokak, No:14/8 $\quad$ Osmanağa Mahallesi, Mürver Çiçeği Sokak, No:14/8

Kadıköy - ISTANBUL / TURKIYE 34714 Kadıköy - ISTANBUL / TURKEY 34714 e-posta: editor@rumelide.com e-mail: editor@rumelide.com, tel: +90 505 7958124, +90 216773 o 616 phone: +90 505 7958124, +90 2167730616 
of the dictionary. In this study, some sample words taken from the Türk Lügati are compared with the same words taken from general dictionaries, etymology dictionaries, dialect science dictionaries, idioms and proverbs dictionaries. In the comparison, the positive and negative criticisms of the researchers on the dictionary were also taken into consideration. It is possible to correct the deficiencies and mistakes in this work with the attention and effort of lexicographers. The vocabulary of this large-volume, database-wide dictionary should be presented to the user with different syntax according to lexicology technique. Thus, it will become an easy-to-use dictionary.

Keywords: Türk Lügati, lexeme unit, dialect, lexical unit, typesetting essay

\title{
Giriş
}

Türk Lügati geniş oylumlu bir eser olup, Hüseyin Kazım Kadrî tarafından etimolojik, karşllaştırmalı ve örnekli bir sözlük olarak hazırlanmıştır. Birkaç kez kontrolden geçirilen eserin Garb Türkçesi bölümü hatasız ortaya konulmuştur. Türk lehçeleriyle ilgili bölümlerde ise durum farklıdır. Bu bölümler hataların çokluğu sebebiyle eleştirilmiştir. Başka bölümlerde olmayan kelimeler, açıklamalar ve isabetli tanıklar sözlük kullanıcıları için -İsmail Gaspıralı, Cemil Meriç gibi yazarlar eseri övmüş̧ür (Öbek, 2009, s. 851-852)-faydalı olmaktadır. Yavuzaslan, sözlükbilim tekniği açısından zayıf olan bu sözlüğü Osmanlı döneminde hazırlanan Türk sözlüklerine almamıştır (bk. Yavuzaslan, 2009). Türk Lügati üzerine çalışma yapan Öbek, TDK’nin bu sözlüğü gün yüzüne çıaracağını ifade etmesine rağmen henüz bir gelişme olmamıştır:

\begin{abstract}
"Son olarak sevindirici bir gelişme ile sözlerimizi bağlamak istiyoruz: Süleyman Nazifin yukarıda alıntıladığımız; hâlâ tab' u neşr edilmemesi irfânımız için hüsrân bulunan -iki mânâsıyla daBüyük Lûgat’i nihayet Türk Dil Kurumu, gündemine almış ve yayımlama kararı almıştır: Yayımı, iki aşamah tasarlanmıştır: İstanbul"un dünya kültür başkenti ihtifalleri çerçevesinde (2010) gerçekleşmesi beklenen birinci aşama sözlüğün örneklerden arımış halini kapsamaktadır. İkinci ve son aşamada ise bütün tanıklarıla, tam metin yayımı hedeflenmiştir.” (Öbek, 2009, s. 854).
\end{abstract}

Türk Lügati üzerine akademik çalışmalar ve tezler devam etmektedir. Tarihî süreçte kişilerin başlattığı geniş oylumlu sözlüklerin genellikle bitirilemediği ve başkaları tarafından tamamlandı̆̆ı görülür. Yazıldığı dönemde kontrolünün iyi yapılamaması ve baskı hataları, sözlüğün değerini düşürmüştür. Türk birliğini lisanda sağlamayı düşünen Kadrî eserinin iki cildinin, Eren’in söz konusu ettiği ve birçok sözlüğün başına gelen posthume 2 sözlük baskısı olmasına müsade etmemiştir (bk. Eren, 1999, s. XX). Eserin son iki cildi ise Kadrî̀nin ölümünden sonra basılmıştır. Kadrî zamanında yazılan eserlerin büyük bir kısmının edisyon kritiği yapılırken, Türk Lügati hâlâ canlandırılmayı beklemektedir.

\section{Türk Lügatinin düzeni ve özellikleri üzerine yapılan eleştiriler}

Adından çok söz edilen ve çok eleştirilen $T L$, kendine has bazı özellikler taşımaktadır. Dört cilt hâlinde yazllan eserin ilk iki cildinin Arap harfleriyle, son iki cildinin ise harf devrimi nedeniyle Latin harfleriyle basılması ilginçtir. Sözlükbilimi açısından çok eleştirilen eserin içeriği ile ilgili henüz geniş çaplı araştırma ortaya konmamıştır. Kaçalin, $T L$ ’nin tanıtımını yaptığı yazısında müellifin amacını şöyle açlklar: "Müellif, eserine yazdı̆̆ı uzunca önsözde amacının çeşitli Türk lehçelerindeki dil bilgisi özellikleriyle Batı Türkçesỉnin söz dizimi kuralların ortaya koymak, Türk dillerinin bir asıldan türediğini göstermek ve bu yolla dil birliğine gitme imkânını sağlamak olduğunu söyler." (Kaçalin,

Ölüm sonrası. Eserin son iki cildi posthume basılmıştır.

Adres

RumeliDE Dil ve Edebiyat Araştırmaları Dergisi Osmanağa Mahallesi, Mürver Çiçeği Sokak, No:14/8 Kadıköy - ISTANBUL / TÜRKIYE 34714 e-posta: editor@rumelide.com tel: +90 $5057958124,+902167730616$

Address

RumeliDE Journal of Language and Literature Studies

Osmanağa Mahallesi, Mürver Çiçeği Sokak, No:14/8

Kadıköy - ISTANBUL / TURKEY 34714

e-mail: editor@rumelide.com

phone: +90 505 7958124, +90 2167730616 
2012, s. 544). Kaçalin, dil birliğini sağlamak amacıyla yazılan $T L$ ’nin önemli bazı özelliklerini açılamaya şöyle devam eder:

\begin{abstract}
“Türk Lugatı esas itibariyle Batı Türkçesinnin yanı sura Uygur, Çağatay, Âzerî ve Kazan lehçeleriyle diğer bazı lehçelerden alınmıs kelimelerin etimolojik (kök esasına dayalı), mukayeseli ve edebî (örnekli) bir lugatıdır. Hüseyin Kâzım, çeşitli ülkelerde ve farklı zamanlarda kullanılan Türk dilleri ve lehçeleri üzerinde durup örnekler vermiş, daha sonra Batı Türkçesỉnin alfabesi, kelime türleri ve özellikleriyle ilgili açıklamalar yapmıştır... Türk Lugatı'nın tertibi elif harfinden başlayıp ye harfine kadar otuz üç harf üzerinedir... Dört büyük cilt içinde örnek olarak verilen deyim, atasözü, beyit ve cümleler müstakil birer çalışma teşkil edecek mahiyettedir... Sözlük etimolojik ve mukayeseli şekilde hazırlandığı için diğer sözlüklerden ayrılır. Madde başları kelimelerin kök biçimlerinden oluşmakta, türemiş kelimeler bunun altında verilmektedir. Sözlük maddelerinde kelimelerin çeşitli Türk lehçelerindeki biçimleri ayrı ayrı kaydedilmekte, bu maddelerle ilgili örnek metinler, atasözleri ve deyimler yazılmakta, ayrıca yabancı kelimelerin hangi kökten geldiği açlklanmaya çalışılmaktadır... Başka sözlüklerde bulunmayan birçok kelime, terkip ve terimi içermesi eserin zenginliğini ve farkhlığını ortaya koymaktadır.” (Kaçalin, 2012, s. 545).
\end{abstract}

Lügatin muhtevası ve zayıf tarafları konusunda açıklanan yukarıdaki fikirlerin benzerlerini daha önce Mehmet Şakir Ülkütaşır da ileri sürmüştür: 1. Osmanlıca bakımından oldukça iyi ve zengindir. 2. Azeri ve Kazan ile Orta Asya Türk lehçelerine ait kısımlarında epeyce yanlıştır. 3. Bu lehçelerdeki birtakım kelimeler ya yanlış okunmuş yahut verilen tanıklar o kelimenin anlamına pek uygun düşmemiştir. 4 . Lügatte bazı başı davalı kelimeler ya şahitsiz kaydedilmiş yahut hiç kaydedilmemiştir. 5. 'Büyük', 'Ağaç', 'At' gibi birtakım kelimeler de faydasız yere bir çok atalar sözü ve başka misallerle doldurulmuştur. 6 . Lügate alınan Kıpçak, Kazan-Kırgız, Selçuk, Uygur, Oğuz, Cengiz vb. boy, kişi adları hakkında verilen etnik ve tarihi bilgiler eski kitapların yazılarını tekrarlamaktan ibarettir (Görel, 2019, s. 22-23).

\title{
II. Türk Lügati için yapılması gereken çalışmalar
}

TL gibi geniş oylumlu ve hatalı olan Burhan-ı Katı' Lügati müellifine de yukarıdaki eleştirilere benzer eleştiriler yapılmıştır. M. Hüseyin Tebrizî; Pehlevi, Deri, Pazend dillerinin kelimelerini Arapçaya bağlaması, Yunanca ve Latince kelimeleri karıştırması, şahıs ve belde isimlerinde hataya düşmesi, el yazmalarından kelimeleri yanlış okuması, hurafeleri gerçekmiş gibi vermesi ve kelime şahidi olarak şiirlerin olmaması gibi hatalar yönünden eleştirilmiştir. Yine de eserin tekrar basımı farklı araştırıcılar tarafından yapılmıştır. Araştırmacılar, -araştırmacılardan sekizinin adı ve eseri örnek olarak verilmiştirBurhan, Katı ve Burhan-ı Katı kelimelerinin önüne cami, katı, muhrik, satı gibi eklemeler yaparak eserlerine farklı isimler verip, daha hacimli ve daha doğru eserler meydana getirmişlerdir. Mütercim Asım da böyle bir çalışmanın mahsulü olarak Burhan-ı Katı 'Tercümesi isimli eseri ortaya koymuştur (Öztürk \& Örs, 2009, s. XII). Aynı eleştirilere tabi tutulan Farsça Burhan-ı Katı böyle geliştirilirken, Türkçe $T L$ ise kendi hâline terk edilmiştir. $T L$ de sözlükbilim, lehçeler sözlüğü, etimoloji sözlüğü vb. bağlamda taşıdığı değerler bakımından incelenmeli, edisyon kritik yapılarak herkesin kolay erişebileceği şekilde yayımlanmalıdır. Bedros Keresteciyan hazırladığı Türk Dilinin Etimolojik Sözlüğünü etimolojik sözlük olarak adlandırmakta ve günümüzde de hatırı sayılır kullanıcısı bulunmaktadır. Keresteciyan’ın sözlüğünden alınan örnekler sebebiyle eleştirilen Kadrînin kendi eserini iştikaki sözlük olarak tanıtmasında haklılık payı yok mudur? Bugün birçok sözlük kullanıcısı, ulaşım ağlarında kelimeler hakkında -doğru veya yanlış olsun- Keresteciyan'ın açılamalarına benzer basit açıklama bulduklarında beğeni ifadeleri bırakıp yetinmekte, daha ileri bir bilgiye ulaşmayı düşünmemektedir. Ayrıca divan edebiyatı araştırmacıları da, mazmunların çok iyi derlendiği, tanıkların tam ve doğru olarak

\footnotetext{
Adres | Address

RumeliDE Dil ve Edebiyat Araştırmalar Dergisi Osmanağa Mahallesi, Mürver Çiçeği Sokak, No:14/8 Kadıköy - ÍSTANBUL / TÜRKIYE 34714 e-posta: editor@rumelide.com tel: +90 505 7958124, +90 2167730616

RumeliDE Journal of Language and Literature Studies Osmanağa Mahallesi, Mürver Çiçeği Sokak, No:14/8

Kadıköy - ISTANBUL / TURKEY 34714

e-mail: editor@rumelide.com,

phone: +90 5057958124 , +90 2167730616
} 
The comparison of Türk Lügati dictionary with different types of dictionaries and an attempt on its arrangement / B. Sarıkaya (pp. 403-430)

kaydedilmediği ansiklopedik sözlük $T L$ 'nin belli maddelerinden aldıkları şiirlerin değerinden ziyade metnin tesisi üzerinde zaman harcamaktadır. 3

Başka sözlüklerde yer almayan kelimeler ve deyimler ile dikkat çeken TL’nin sözlükbilimi açısından değerlendirilebilmesi için yapılacak çalışmaların ilki, metnin çeviri yazısının kaynaklardan teyit edilerek ortaya konması olmalıdır. Şimdilik lügatle ilgili çalışmalar birkaç tezden ibarettir.4

\section{Sözlük türleri ve özellikleri}

Sözlük, bir dilin (ya da birden çok dilin) sözvarlığını, söyleyiş biçimleriyle, yazımlarıla veren, bağımsız biçimbirimleri temel alarak bunların, başka öğelerle kurdukları söz öğeleriyle birlikte anlamlarını, değişik kullanımlarını gösteren bir sözvarlığı kitabı (Aksan, 2009, s. 75). Aksan, tanımını yaptığı sözlükleri üç farklı yönden öbeklendirir: Sözlük birinci olarak dilin sözvarlığı işlenirken kullanılan dillere göre tekdilli ve çokdilli olarak ikiye ayrılır. İkinci olarak dilin sözvarlığının abecesel sıralanmasına veya bir kavram etrafında kümelenmesine göre abecesel sözlükler ve kavram sözlükleri olarak ikiye ayrılır. Sözlük üçüncü olarak, ele alınan sözvarlığının niteliklerine göre; a) Genel sözlükler (ortak dil, yazı dili sözlükleri, ansiklopedik sözlükler). b) Lehçebilim sözlükleri. c) Eşanlaml, eşadlı, tersanlamlı öğeler sözlükleri. ç) Yabancı öğeler sözlükleri. d) Tarihsel sözlükler. e) Kökenbilgisi sözlükleri. f) Uzmanlı alanı sözlükleri (terim sözlükleri). g) Argo sözlükleri. h) Deyim ve atasözü sözlükleri. ı) Anlatımbilim sözlükleri. i) Sanatçı ve metin sözlükleri. j) Yanlış yerleşmiş öğe sözlükleri. k) Tersine sözlükler olmak üzere on üçe ayrılır. Sözlükler kuruluş gayesine ve yapılarına göre başka türlerinin bulunduğu ifade edilir (Aksan, 2009, s. 75-83).

$T L$, yukarıda anılan sözlük türlerinden bir kısmının bazı kuramsal ve uygulama özelliklerini taşıdığından bu sözlük türlerine uygun düzenlenebilir ve okuyucuya sunulabilir.

\section{Türk Lügatinin yeniden düzeni ve farklı sözlük türleriyle düzenlenebilirliği}

Bu çalışmada Kadrî̀nin 190o'lü yılların başlarında yazdığı ve birçok araştırmacı tarafından tenkit edilen $T L$ sözlüğü, Aksan'ın tasnifindeki sözlük türlerine göre incelenecektir. Sözlükbilimin gelişimi ve sözlük alanındaki dijitalleşme, sözlüklerin basımında bazı yenilikler ve değişiklikler yapılmasını gerekli kılmaktadır. TL, farklı sözlük türleri özelliklerini taşımaktadır. Sözlüğün madde başları ve içerikleri farklı sözlük türlerine göre incelenip karşılaştırılmalı, farklı teknikler uygulanmalıdır. Böylece sözlükteki bazı değerlerin ön plana çıması ve hataların belirlenip düzeltilmesi sağlanmalıdır.

$T L$, farklı türdeki sözlüklerle mukayese edilmiş, sözcük birimleri örnek sözlükteki sözcük birimlere göre düzenlenmiş, belli oranlarda o sözlüğün özelliğini taşıyıp taşımadı̆̆ı tespit edilmiştir. Önce tekdilli/çokdilli ve abecesel/kavramsal örnek sözlüklerindeki sözlük birimleri ele alınarak uygulama

3 İnce, Z. (2015). Türk Lügatı'nda "B" ile bașlayan kelimelerle ilgili șiir örnekleri. (Yayımlanmamış Yüksek Lisans Tezi). Atatürk Üniversitesi / Sosyal Bilimler Enstitüsü / İslam Tarihi ve Sanatları Anabilim Dalı, Erzurum.

Öbek, A. İ. (1999). Büyük Türk Lügati `nde divan edebiyatı unsurları. (Yayımlanmamış Doktora Tezi). Trakya Üniversitesi, Sosyal Bilimler Enstitüsü, Türk Dili ve Edebiyatı, Edirne.

Çakır, F. (2019). Türk lugatında c ve ç ile başlayan kelimeler ve şiir örnekleri. (Yayımlanmamış Yüksek Lisans Tezi). Atatürk Üniversitesi, Sosyal Bilimler Enstitüsü, Türk Dili ve Edebiyatı, Erzurum.

Gürgen, A. (2014). Büyük Türk Lügatında Elif harfi ile başlayan kelimelerle ilgili şiirler (C.I, S. 181-370) . (Yayımlanmamış Yüksek Lisans Tezi). Atatürk Üniversitesi, Sosyal Bilimler Enstitüsü, İslam Tarihi ve Sanatları Anabilim Dalı, Erzurum.

Yıldıztaş, A. (2012). Türk Lügatı'nda Elif ile başlayan kelimelerle ilgili şiirler: C. I, s. 371-559. (Yayımlanmamış Yüksek Lisans Tezi). Atatürk Üniversitesi, Sosyal Bilimler Enstitüsü, İslam Tarihi ve Sanatları Anabilim Dalı, Erzurum.

$4 \quad$ Görel, Ö. (2019). Türk Lügati'nde "Dal" maddesi (Metin-dizinler-sözlük). (Yayımlanmamış Yüksek Lisans Tezi). Afyon Kocatepe Üniversitesi / Sosyal Bilimler Enstitüsü / Türk Dili ve Edebiyatı Anabilim Dalı, Afyonkarahisar.

Topaloğlu, N. (2018). Türk Lügatı'nda "P" ile başlayan kelimeler ve ilgili şiir örnekleri. (Yayımlanmamış Yüksek Lisans Tezi). Atatürk Üniversitesi / Sosyal Bilimler Enstitüsü / İslam Tarihi ve Sanatları Anabilim Dalı, Erzurum.

Adres $\mid$ Address

RumeliDE Dil ve Edebiyat Araştırmaları Dergisi Osmanağa Mahallesi, Mürver Çiçeği Sokak, No:14/8 Kadıköy - İSTANBUL / TÜRKIYE 34714 e-posta: editor@rumelide.com tel: +90 $5057958124,+902167730616$

RumeliDE Journal of Language and Literature Studies Osmanağa Mahallesi, Mürver Çiçeği Sokak, No:14/8

Kadıköy - ISTANBUL / TURKEY 34714

e-mail: editor@rumelide.com,

phone: +90 505 7958124, +90 2167730616 
özellikleri ortaya konmuştur. Sonra TL'deki sözlük birimleri özellikleri ve farklılıklar belirtilmiştir. Üçüncü olarak yazılış amacına, hitap ettiği kesimlere ve niteliğine göre tasnif edilen sözlüklerin sözlük biriminin uygulama şekli incelenmiş, alınan örnek sözlükteki sözlük birim uygulamaları TL'deki sözlük birimlerinde denenmiştir.

\section{A. Türk Lügatinin sözvarlığı işlenirken kullanılan tekdilli ve çokdilli sözlük özellikleri}

$T L$, tekdilli sözlüğe örnek kabul edilebilir. Madde başı deveran, dağhk ve dallanmak kelimeleri tekdillilikle ilgili sözlüklerin özelliklerini gösteren örneklerdir. Bu kelimelerin anlamı anlaşılan ve günlük hayatta kullanılan kelimelerle verilmiştir: deverān "devr etmek, dönmek, aylanmak." (Görel, 2019, s. 47), dağllk "dağları çoḳ olan yer, dağllk" (s. 70) ve dallanmaḳ "ağaç dal vermek; (mecāzen) mübalağa edilmek; iş müşkilata düşmek” (s. 76) şeklinde anlamlandırılmıştır.

Yukarıdaki örneklerle birlikte bazı madde başı kelimeler, kelime grupları ve bunların tanıkları ise; farklı bir dilin yapı özelliğini taşıdığı için, sözlüğü tekdilli olmaktan çıarmaktadır. Bunun için "dâl” harfindeki devlet-mend, dāïre-i istivā, dād-bahş, dād-rāst, kevkeb-i dürrī ve dadis örnekleri gözden geçirilebilir:

a. Farsça yapılı devlet-mend kelimesine devlet ve saadet sahibi anlamı verilmiş, sonra Sadî’nin Farsça şiiri tanık olarak sunulmuştur (TL, II, s. 694).

$$
\text { هر كه با اصل خود وفا نكند / / نشود دوست روى و دولتمند }
$$

b. Farsça isim tamlaması dā’ire-i istivāy ya Arapça-Farsça karma yapısıyla iki karşıllı verilmiş, arasına Türkçe veya bağlacı getirilmiştir: dā’ire-i nışf'n-nehār veya mu'addilü 'n-nehār gibi (TL, II, s. 683).

c. dād-bahş kelimesinin anlamı 'adl ü dād iden; -mecāzen- Allah şeklinde verilirken tanığı Nizamî̀nin Farsça bir beyitidir (TL, II, s. 680).

$$
\text { بنام بزرك ايزددادبخش / / كه مار ازهر جيز او داد بخش }
$$

ç. dād-rāst kelimesi ‘ādil, münșif anlamlı olup, tanı̆̆ı Firdevsînin aşağıdaki Farsça bir beyitidir (TL, II, s. 680).

$$
\text { جو كرده شد سام برياى خاست / / بكفت اى كزين مهتر داد راست }
$$

d. Madde başı dürrī kelimesine parlak, münevver, rahşān anlamı verilirken buna bağlı alt maddede

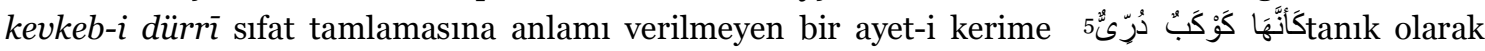
yazılmıştır ve herhangi bir açıklama yapılmamıştır (TL, II, s. 716).

e. dadis kelimesi, yeji yürümeye başlayan çocuḳlar içün ķullanılur şeklinde bir cümleyle anlamlandırılmıştır. Tanığı ise "C'est le même mot-que le fraçais - dada. L' expression anglaise - todade au ckild = apprendre à marcher à un enfant. Ce vocable turc. Ou sa forme, semble avoir été introduit dans cette langue, par I'nntermédiaire du grec moderne. Bedrus Efendi Kerasteciyān"6 şeklinde ikinci bir dil olan Fransizca ile verilmiştir (TL, II, s. 680).

“... sanki inci gibi parlayan bir yıldız...” (Nur, 24/35)

“Aynı Fransızca kelime - dada. İngilizce ifade - todade au ckild = bir çocuğa yürümeyi öğretmek. Bu Türkçe kelime veya biçimi, modern Yunanca aracıllı̆̆yla bu dile getirilmiş gibi görünüyor.” Bedrus Efendi Kerasteciyān.

Adres | Address

RumeliDE Dil ve Edebiyat Araşturmalar Dergisi $\quad$ RumeliDE Journal of Language and Literature Studies

Osmanağa Mahallesi, Mürver Çiçeği Sokak, No:14/8 $\quad$ Osmanağa Mahallesi, Mürver Çiçeği Sokak, No:14/8

Kadıköy - ISTANBUL / TÜRKIYE 34714 Kadıköy - ISTANBUL / TURKEY 34714

e-posta: editor@rumelide.com e-mail: editor@rumelide.com,

tel: +90 505 7958124, +90 2167730616 phone: +90 505 7958124, +90 2167730616 
Yukarıdaki kısa örneklerden anlaşılacağı üzere tekdilli bir sözlük gibi görülen $T L$ 'deki tanıkları sadece Türk dilini bilen kişinin algılaması mümkün değildir. Örneklerdeki bazı kelime grupları ve cümle halindeki birtakım Farsça, Arapça ve Fransızca tanıklar Türkçeden farklı dil yapı özelliklerini taşımaktadır. O hâlde maddelerin bazılarına bakarak $T L$ çokdilli sözlüğe örnektir denilemez. Bu sözlüğün başlı̆̆ına çokdilli sözlükler gibi ikinci bir dil adı eklenemez. Eserin tamamı kavrandıktan sonra Arapça, Farsça, Kazakça, Türkmence vb. belli bir dil veya lehçe ile ilişkilendirilerek o dil veya lehçe ile ilintili eksik bir sözlük çalışması ortaya konabilir. Böyle bir çalışma da ancak belli başlı konularda iki dilin etkileşimini ortaya çıarmada örnek bağlamında yardımcı olabilir.

Öte yandan çokdilli sözlük Aksan'a göre tercüme için hazırlandığı gibi, dillerarası akrabalıkları tespit için (Meyer - Lübke'nin Roman Dilleri Kökenbilgisi Sözlüğü ve Alois Walde’nin Hint - Avrupa Dillerinin Karşılaştırmah Sözlüğü) ve anında çeviri için de (Peter M. Berkman'ın derlediği İngilizce 1000 kelimenin 26 farklı dildeki karşılığı ile oluşturulan The Concise Dictionary of 26 Languages adlı sözlük) hazırlanabilir (Aksan, III, 2009, s. 70-71).

Hedefi Türk birliğini sağlamak olan Kadrî, birbirinden ayrı yaşayan ve birbirinin dilini anlamayan aynı kanı taşıyan Türkiye, Kazan, Kazak vb. Türklerinin kullandığı kelimelerin farklılıklarını ve benzerliklerini, lehçelerin akrabalıklarını ortaya çıkarmak ister. Madde başı olarak alınan kelimenin yanına Garb Türkçesi, Kazak, Azeri gibi dil belirtildiği için, "aynı dili konuştukları hâlde siyaset gereği birbirinden koparılmış milletlerin ortak kelimelerinin sözlüğü” anlamında çoklehçeli sözlük kavramı kullanılabilir.

"Efradın cami ağyarına mani” bir başlık taşımayan birçok sözlük, daha kullanıma başlamadan önce anlam kargaşasına sebep olmaktadır. Mesela Eren, sözlüğünde madde başı olarak aldığı kelimeyi bütün lehçelere göre incelemiştir. Bu eserin Türk Dilinin Etimolojik Sözlüğü olarak isimlendirilmesi uygundur. Ercilasun, 1990'larda SSCB'den bağımsızlığını kazanan Türklerin, Türkiye Türkleriyle anlaşabilmesini sağlayacak olan ve 7000 kelimenin 9 Türk lehçesinde karşılığını verdiği Karşılaştırmalı Türk Lehçeleri Sözlüğü hazırlamıştır. Nüfusu bir milyondan fazla olan kavimlerin lehçelerinin alınıp diğerlerinin alınmaması (Ercilasun, 1992, s. IX), birçok Türk lehçesini bu sözlük kavramının dışında bırakmıştır. Her iki sözlük de belli kuramsal özelliklere göre yazılmıştır. Türk milletinin birliği için yazılan ve sözlükbilim kurallarına uygun yazılmayan $T L$ 'nin tenkit edilen özelliklerinden biri, yukarıdaki sözlüklerin aksine keyfi olarak kurala bağlı olmadan farklı lehçelerden örnekler seçmesidir. Bazen madde başları, anlamı verilmeyen Arapça, Farsça vb. gibi dillerin tanıklarıyla açıllandığı için, Türk Lügati çoklehçeli sözlük olma görünümünden çıkarak çokdilli sözlük görünümüne bürünür.

Özetle TL'nin Türk lehçeleri alanında bazı güvenilmez bilgiler içerdiği söylenebilir. Lehçelere ait güvenilmez bilgiler düzeltilmeli, tarihî değeri olan sözlüklerden biri hâline getirilmeye çalışılmalıdır. Sözlüğü tek başına hazırlayan Kadrî, bazı maddelerde sözlükçülüğün gereğini yaparken, bazı maddelerde derlediği tanıkları işleyememiştir. Sözlüğe alınan bazı yabancı kelimelerin tanığı, Türkçe olmayan bir metin olarak karşımıza çıkar. Bu kısımları ikidillilikten kurtarmak için de yapılacak çalışmada dipnotlar, parantezler içerisinde açıklamalar ve yardımcı bilgiler sunulmalıdır. Kadrî, edebiyatçılarla birlikte sözlük çıkarma işine girişmiş ama arkadaşları tarafından yalnız bırakılmıştır. Türk Lehçeleri kısımlarındaki sözlük verileri işlendiği takdirde müellifin arzusu yerine getirilmiş olacaktır. Zaten geniş çaplı sözlük calışmaları, bireysel hazırlanabilecek ve aceleye getirilecek çalışmalar değillerdir.

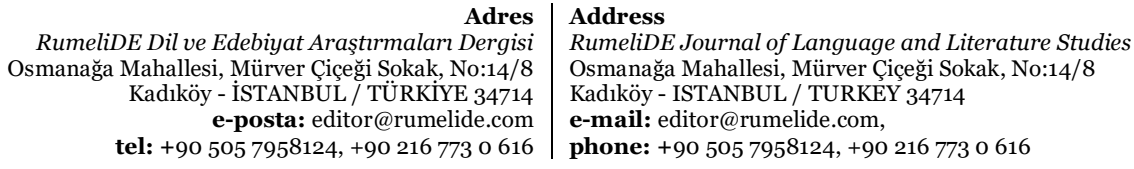




\section{B. Türk Lügati’nin sözvarlığı işlenirken kullanılan abecesel sözlükler ve kavram sözlükleri (adbilimsel/onomastik) özellikleri}

TL’de Türkçenin sözvarlı̆̆ı abecesel/elifba sistemine göre düzenlenmiştir. Bilindiği üzere tarama, harflerin sırasına göre yapılır. Sözlüklerde kelimelerin harf sırasının dizimi farklı şekillerde olur: a. Madde başının ilk harfi ve ikinci harfi. b. Madde başının ilk harfi, son harfi. c. Madde başının son harfi ve ilk harfi gibi.

Aşağıda grup halinde iki örnek ele alınmıştır. Bu örneklerdeki kelimelerin dizilişi tamamen elifba sırasına göre olup, anlamsal bir dizgi söz konusu değildir. Birinci örnek elif maddesinden alınmıştır: افول

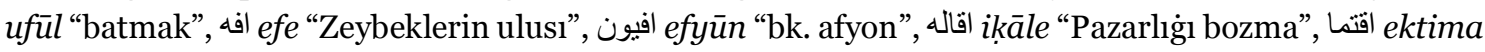
"bir cilt ḩastalığı, egzama" (TL, I, s. 257) gibi.

Dâl harfinden alınan ikinci örnek madde başlarının dizgisi de elifba sırasına göre yapılmıştır: دala

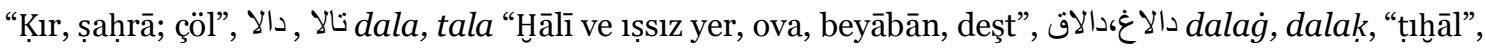

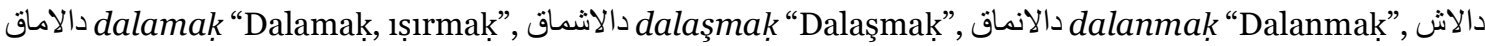
dalaş "Dalaş, gürültü” (TL, II, s. 696) gibi.

Eserle ilgili yapılan alfabetik dizginin bozulması yönündeki eleştirilerin örnekleri ise, iç maddelerde görülmektedir. Eserde alfabetik dizgi görünmüyorsa madde içlerinin dizgisinin sistemi hakkında aşağıdaki örnekler incelendikten sonra karar verilebilir.

دür madde başına ait alt maddede alınan tamlamaların madde dizgisi aşağıdaki gibi yapılmıştır:

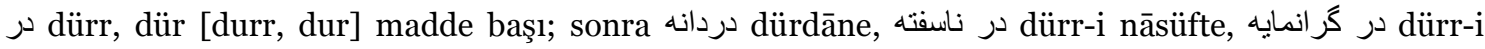

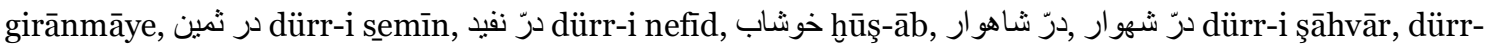

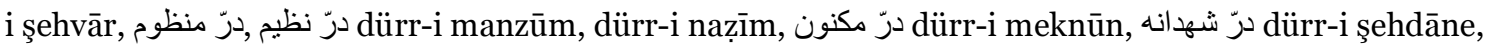

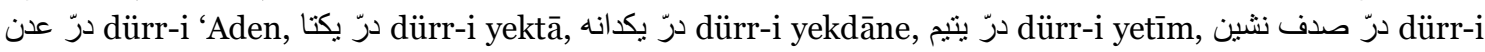

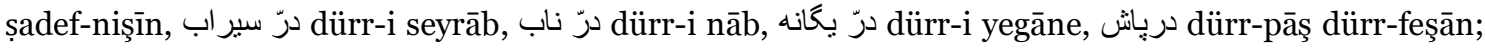
dürr-perver...

İç maddelerde dürr kelimesiyle yapılan yirmi tamlamanın alfabetik olmadığı açıktır, bu maddelere 41 şiir tanığı sunulmuştur. Tekrar iç maddede kelimenin müennesi, çokluğu ve ism-i mensubu alfabetik olmayan bir sıralama ile şöyle alınmıştır: درّه dürre [durré], درر dürer [durér], درّى dürrī [durrī] (TL, II, s. 714-715).

İkinci olarak madde başı دل dil kelimesini inceleyelim. Edebi değeri olan ve kendisiyle kurulan tamlamalar ara madde olarak ele alınıp, istisnasız herbiri tanık şiirlerle açıklanmıştır. Gönül anlamına gelen bu kelimede 197 tanık vardır; beşi nesir diğerleri şiirdir. Madde başı dil kelimesinden sonra üç darb-ı mesel verilir, sonra tamlamalara geçilir; sırasıyla dil-ārā, dil-ārām, dil-āzār, dil-āşūb, dil-āsūde, dil-āgāh, dil-āver, dil-āzerde, dil-āşüfte;dil-āşüfte, dil-āviz, dil-āzād, dil-efrūz, dil-bāz, dil-ber, dilbeste, dil-i bị-karāar, dil-pesend, dil-pežirr, dil-teng, dil-teşne, dil-cū, dil-çālāk, dil-ḩırāş, dil-ḩarāb, dilhaste, dil-h̆vāh, dil-h̆ūn, dil-dār, dil-dāde, dil-dūz, dil-dānā/dil-divāne, dil-rübā, dil-ri̧ş, dil-rubūde, dilzār, dil-zinde, dil-sitān, dil-sūhthe, dil-sūz, dil-sūzān, dil-şiken, dil-sįr, dil-şād, dil-i nā-şād, dil-şude, dilşikār, dil-şikāf, dil-şikeste, dil-şeydā, dil-şiken, dil-şikest, dil-şüküfte, dil-i şad-çāk, dil-furūz, dil-firib, dil-figār/dil-efgār, dil-ferā, dil-germ, dil-keş, dil-gūr, dil-güşā, dil-güdāz, dil-gịr, dil-mürde, dil-nişi̧n, dil-nuvāz, dil-nālān tamlamaları ile devam etmiş, sonra dil vermek ve dil bag்lamaḳ deyimleri ve son olarak madde içi dilber ve dilberį türemiş kelimelerle son bulmuştur. (TL, II, s. 752-760). Dil kelimesinin

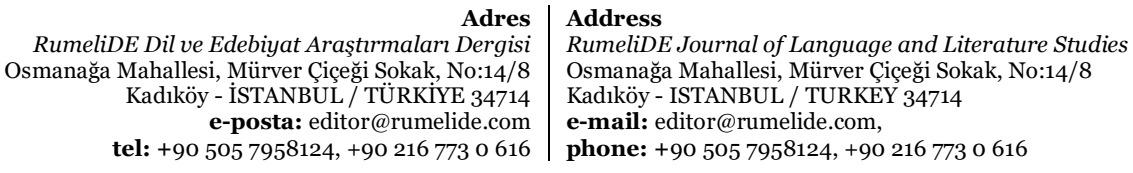


alt maddesi dil-ber kelimesinde gerçek anlam, mecaz anlam, darb-ı meseller ve tanıklar sunulmuştur. dil-keş kelimesinde de aynı sıralamayla gerçek anlam, mecaz anlam, terim anlam ve sonra tanıklar verilmiştir (TL, II, s. 760).

Üçüncü olarak madde başı balta kelimesi -Aşă̆ıda ayrıntılı bir şekilde ele alınacaktır- madde başı yapıldıktan sonra ara maddeler alfabetik devam etmez. Sırasıyla darb-ı meseller, özel anlam kazanan birleşik yapılar, gerçek anlamını kaybetmeden kurulan tamlamalar, fiille biten deyimler ve türemiş olan kelimeler yer alır (TL I, s. 632).

Yukarıda açıklanan üç madde başına göre TL'de madde başı kelimeler alfabetik olarak dizilirken alt maddelerin düzeninin alfabetik yapılmadığı ve belli terimlere göre şöyle yapıldığı söylenebilir:

1. Darb-ı meseller başlığı atılıp, altında kelimenin yer aldığı cümle yazılır: Balta degmedik ağaç olmaz ve Baltayı asdı gibi.

2. Darb-ı mesellerden sonra özel anlam kazanan birleşik yapılar yazılır: Bu yapıyı çözmek için mutlaka öğrenilecek bilgiye ihtiyaç duyulur. Terim anlamı kazanan sözlükte tarif edilmesi gereken isim hâline gelmiştir. Tamlayan ve tamlananı bilmek tamlamanın anlaşılması için yeterli olmaz: dil-āşūb, dil-āsūde, dil-gūr dil kelimesinin gönül olması bu tamlamaları tam anlamaya yardımcı olmaz, tamlama mecaz anlamlı olduğundan tanımını sözlükten öğrenmek gerekir.

3. Gerçek anlamını kaybetmeden özel ad gibi kullanılan tamlamalar: Bunların bir kısmının anlamını verirken bir kısmının anlamını vermeden sıralaması yapılır: Balta sapı; eger baltasl; hacamat baltası... gibi.

4. Deyimler mastar hâlinde yazılarak anlamı verilir: dil vermek, dil baġlamak gibi.

5. Türemiş kelimeler genel sözlüklerde madde başı olurken, burada madde içi olarak yazılır: dür madde başında dürre, dürer, dürrī, madde başı balta kelimesinden sonra baltacı, baltalu, baltalık, baltalamak gibi.

Alt maddeleri abecesel dizilmeyen $T L$ 'de kavramlara veya alanlara göre bir düzenleme de olmadığına göre kavram sözlükleri türü açısından değerlendirmek mümkün değildir. Kavram sözlükleri; aynı aileden, aynı gruptan dillerde belli kavramların dile getiriliş biçimini ortaya koyma, böylece, bu dillerde ses ve biçim açısından yakınlıklar, koşutluklar bulunup bulunmadığını belirleme amacıyla ortaya konur... Alman dilcisi Franz Dornseiff in Alman sözvarlığını 20 genel gruba ayırarak hazırladığı Kavram Gruplarına Göre Alman Sözvarlı̆̆ ve Recai Cin’in Kavramlar Dizini bu türe örnek sayllabilir (Aksan, III, 2009, s. 78).

Sonuç itibarıyla TL'nin madde başları dizgisi, basım hataları göz ardı edilirse, alfabetik bir sözlüktür. Alt maddelerde dizgi ise alfabetik değildir. Alt madde olan kelimelerin veya kelimelerin içinde bulunduğu grubun ve cümlelerin; darb-ı meseller, özel anlam kazanan kelime grupları, kendi anlamını koruduğu kelime grupları, deyimler ve türemiş kelimeler şeklinde sıralandığı bir düzeni vardır. Bu durum da herhalde Kadrînin sözlük için ifade ettiği iştikaki sözlük anlayışının sözlükte tezahürü olsa gerektir.

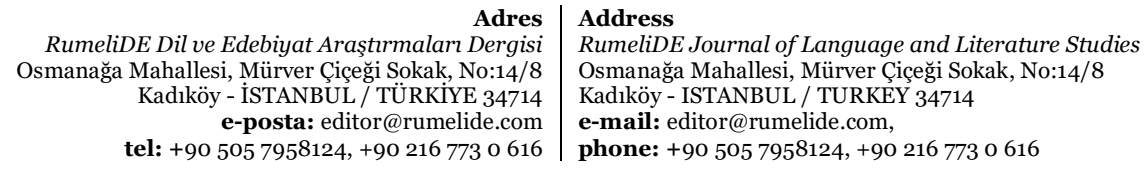




\section{Türk Lügatinin sözvarlığı işlenirken yazılış amacına, hitap ettiği kesimlere ve niteliğine göre taşıdığı sözlük özellikleri}

Sözlükler yazılış amacına, hitap ettiği kesimlere ve eserin niteliğine göre çeşitli isimler alır. Bir bilim dalına mensup olanların kendi alanlarına özel oluşturduğu sözlükler veya bir lehçeye ait sözlük bu türe örnek gösterilebilir. Genelde sözlük hazırlayıcısı tarafından adlandırılırken bu tasnife göre isim verilir. Kadrî, TL’nin dibace kısmında eserinin iştikakî, mukayesevî ve edebî olmak üzere üç özelliğini belirtir:

“Türk Lügati”, Garb lehçesinden başka Uygur, Çağatay, Azeri, Kazan dillerinin ve Uygurcadan ayrlan ve bu nokta-i nazardan bütün Türk dilleriyle uzak yakn bir münasebet arz eden Koybal, Yakut, Çuvaş, Kırgız gibi lehçelerin iştikakî, mukayesevî ve edebî bir Lügat-nâme'si otuz beş senelik mütemadî bir sa'yin hasılası olan bu kitabı Türk dillerinin bir asıldan türediğini göstermek ve atiyen bir "vahdet-i lisaniyye"ye doğru gidilebilmek imkanın hazırlamak için yazdım."(TL, I, s. 1).

Günümüz Türkçesiyle, "Bu sözlük etimoloji sözlüğü, lehçebilim sözlüğü ve edebiyat sözlüğüdür." şeklinde ifade uygun düşebilir. Eser, niteliğine ve yazılma amacına göre bu üç sözlük türüne uygun olarak yazılmış mıdır? Bu mesele, sorularla ve cevaplarıyla şöyle açıklanabilir:

a. TL, dildeki sözvarlığının kökenlerini dilin bütün dönemlerine ve lehçelerine ait verilerle açıklayan sözlükler şeklinde tarif edilen etimoloji (kökenbilimi/İştikak) sözlüğü olup, kelimelerin kökü, eki ve değişimleri hakkında bilimsel metodlarla açıklamalarda bulunmuş mudur?

b. $T L$, dillerin veya lehçelerin karşılaştırılması bakımından ne kadar başarılıdır?

c. Edebî alana ait şiir, nesir vb. veriler fazla olduğu için eser üzerinde tez çalışmaları yapılması, acaba TL’nin edebî alana ait bir edebiyat sözlüğü olduğunu gösterir mi? Edebî kelimesinden maksat kendisinin mi yoksa seçilen örneklerin mi edebî olmasıdır?

TL'yi inceleyenlerin yukarıdaki sorulara verdikleri cevaplar pek de olumlu değildir. Eserin olumlu yönü, edebi örneklerin -her ne kadar gereksiz örneklerden yakınılsa da- iyi derlenmesi, Arapça ve Farsça bilgilerin hatasız olması ve başka sözlüklerde bulunmayan kelime, deyim ve atasözlerinin eserde bulunmasıdır. Birbirinden ayrı kalan bir milletin dil birliğini oluşturmak ve geliştirmek amacıyla yazılan bu sözlüğün Türkiye Türkçesi, Kazan Türkçesi, Azeri Türkçesi vb. lehçelerini kullanan kişiler için faydalı olduğu söylenebilir fakat yeterli olduğu pek söylenemez. TL’nin sözlük değeri, Aksan'ın taksiminde yer alan bazı sözlük türleriyle veya ortaya konmuş sözlük örnekleriyle mukayese edilerek tespit edilebilir.

\section{C.1. Türk Lügati ile genel sözlük örneği Kâmûs-i Türkînin sözlük birim içerikleri bakımından karşılaştırılması}

Genel sözlük, bir dili bütün öğeleriyle ele alan sözlüklerdir. Kâmûs-i Türkî (Şemseddin Samî), Türkçe Sözlük (TDK) ve Misalli Büyük Türkçe Sözlük (Kubbealtı) örnek gösterilebilir. Genel sözlüklere eklenen isimler, kavramlar vb. ile kelimelerin değişimi, gelişimi hakkında verilen geniş bilgiler, bu sözlüğe ansiklopedik sözlük niteliği kazandırır. Osmanlıca-Türkçe Ansiklopedik Lügat (Ferid Devellioğlu) ve Ansiklopedik Divan Şiiri Sözlüğü (İskender Pala) gibi. Genel sözlüklerde madde başı ortaya konulurken dikkat edilmesi gereken bazı mikro yapılar bulunur. Her sözlüğün özelliğine göre yapıların kimisinin geniş, kimisinin ise dar hacimli tutulduğu görülür. "Madde başında bulunması gereken belli başh ana unsurlar şunlardır: Sözcüklerin tanımları, okunuşları, yazılışları, vurguları, hangi dilden oldukları,

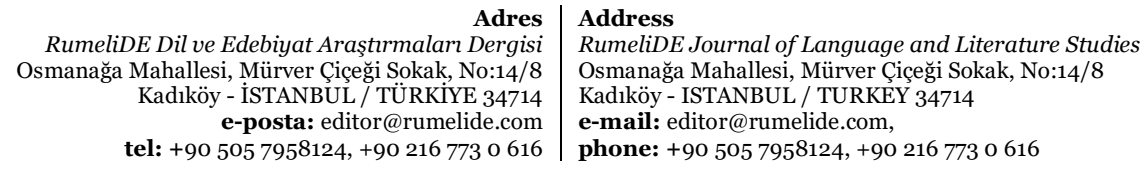


gramer ulamları, sözcüklerle ilgili örnek tümceler, eşanlam ve karşıt anlam bulgusu, çapraz göndermeler, çizim ve resimler.” (Maclaren-Ağbaba'dan aktaran Somuncu, 2020, s. 211).

Milletimizin vahdet-i lisaniyesini sağlayacak olan $T L$ ’yi önce genel sözlükler kısmında incelemek gerekir. $T L$ yi yapı unsurları açısından incelemeye geçmeden önce yapılan tenkitler hatırlanmalıdır. Kaçalin, Ülkütaşır’ın daha önce yaptığı eleştirilerin benzerini barındıran bir yazı ele alır. Kaçalin $T L$ 'nin Türk dili ve lehçeleriyle ilgili kısımlarında kelimelerin yazılışlarında ve okunuşlarında yanlışlıklar bulunması, bazı kelimelerdeki tanık yetersizliği veya anlama uygun düşmeyen tanıklar, bazı tarihî bilgilerin ikinci el kaynaklardan alınmış olması ve bir kısım maddelerin gereksiz yere uzatılması, tartışmalı olan Vámbéry, Bedros Keresteciyan vb. kişilerin eserlerinin kaynak olarak kullanılması ve kaynakçanın dikkatsiz, dağınık hazırlaması eleştirilerin kaynağı olduğunu, bununla birlikte Doğu lehçeleri açısından güvenilemeyeceğini fakat Batı Türkçesi bakımından eserlerinin oldukça zengin bir malzeme ihtiva ettiğini belirtir (Kaçalin, 2012, s. 545).

Kadrî’nin sözlük maddelerini açıklarken kullandığı yapılar tasnif edilirken, aynı zamanda yapılan eleştirilerin göz önünde bulundurulması ve TL'nin daha önce yazılan Kamus-i Türki, Eser-i Şevket gibi sözlüklerle mukayese edilmesi gerekir. TL ile $K T^{\circ}$ yi genel sözlük türü bakımından balta kelimesi örneği bağlamında karşılaştıralım.

\section{a. Kâmûs-i Türkîde balta madde başı}

$K T^{\circ}$ de madde başı balta kelimesi iki anlam taşımaktadır (Sami, 2015, s. 274). Birinci anlamda üç eşanlam bulunmaktadır: sıfat tamlaması, Arapça kelime, Farsça kelime. Sonunda ilintili olan bilgi, köşeli parantez içinde cümle olarak verilmiştir. İkinci anlamdaki iki eşanlam ise, sıfat tamlaması ve bir Farsça kelimeden oluşur: 1. Odun vesaire kesmeğe mahsus saph âlet-i kat', fe's, teber. [Büyüğüne nacak derler] 2. Baltaya müşabih silah, teber. Madde başının anlamı verildikten sonra "//" işareti ile alt maddeler oluşturulmuştur. balta başı maddesinde çapraz gönderme yapılmıştır. balta kelimesiyle oluşturulan deyim veya birleşik yapı Arap alfabesinin ilk harfine göre sıraya girmiştir. Bu 11 alt madde şu şekilde dizilmiştir: aşçı baltası $\approx$, eger baltası $\approx$, balta başı ba.: baş, balta asmak $\approx$, balta sapı $\approx$ baltaya sap olmak , baltayı taşa urmak , balta görmemiş balta girmemiş , balta ile yonulmuş $\tilde{}$, hacamat baltasi $\approx$, marangoz baltasi $\approx$.

Madde başı balta iki tanım ve 11 alt madde ile tamamlanmıştır. Ayrıca balta kelimesinden türeyen dört kelime ise madde başı olarak balta kelimesinden sonra baltacı, baltalamak, baltalı, baltalı olarak dizilmiştir.

\section{Kâmûs-i Türkîdeki balta madde başı düzeninin değerlendirilmesi}

1. Madde başı balta kelimesi Arap ve Latin harfleriyle yazılmış ve dilbilgisi kullanım etiketi w "sîn" ile kelime türü isim olarak etiketlenmiştir.

2. Ara maddeler alfabetik sıraya konmuştur.

3. Lügatte kısaltmalardan faydalanılmıştır.

4. Birinci anlamda fās şeklinde yanlış yazılan kelimenin karşılı̆̆ı çapraz gönderimle arandığında teber madde başının anlamında fe's şeklinde hemzeli yazımla bulunabilmiştir.

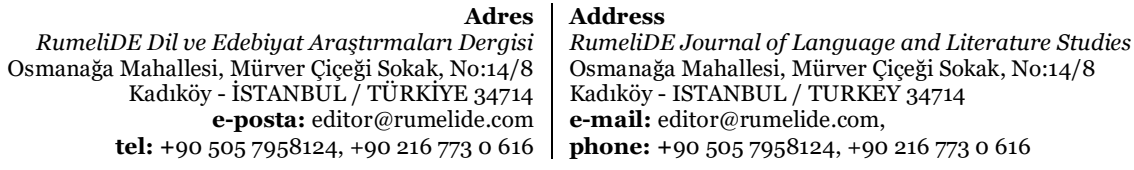


5. balta başı alt maddesinde ba. ile baş kelimesine çapraz gönderme yapılmış, anlam yazılmamıştır.

6. balta görmemiş, balta girmemiş rıka yazısıyla ve kısaltılarak yazılan mec. kullanım etiketi ile anlambilgisine gönderilmiştir.

7. Madde olan kelime veya kelime grubunun tanımı sıfat grubu olarak açıklandığında bu özellik belli bir varlığa veya kişiye mahsus ise, parantez içine o varlık veya kişi yazılarak sıfat tamlaması haline getirilmiştir: (orman), (iş), (adem) gibi.

8. Türemiş kelimeler ayrıca madde başı yapılmışlardır.

Kâmûs-i Türkîde balta ve türevlerinin madde başı içerikleri

\begin{tabular}{|l|l|l|l|l|}
\hline Madde başı & Dili & Kelime türü & Anlamı & Madde içi muhtevası \\
\hline balța & - & s. & Tanım & 2 anlam, 3 birl. i., 6 deyim, 2 terim \\
\hline balțacı & - & s. & Tanım & $\mathbf{2}$ anlam \\
\hline balțalamak & - & f.t. & Tanım & 4 anlam \\
\hline balțalık & - & s. & Tanım & 1 anlam \\
\hline balțalı & - & s. & Tanım & 1 anlam \\
\hline
\end{tabular}

Tablo 1. KT de balta kelimesi ve türevleri.

\section{b. Türk Lügatinde balta madde başı}

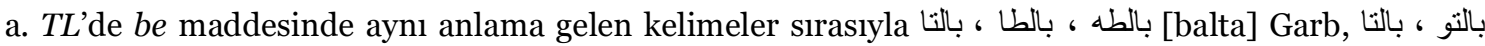
[balta, balto] Çağatay, بالتا [balta] Azeri ve بالتو [balto] Uygur (TL, s. 632) ve balța Kazan (TL, s. 634) şeklinde farklı beş madde başı, Arap harf sistemine göre yerleştirilmiştir. Madde başlarının okunuşu köşeli parantez içinde 1928'lerin Türkiyesindeki Arap harflerinin Latin harflerine çeviri yazı karşılığı ile yazılmışıı.ı.7

Mütercim, TL'de Türkiye Türkçesinde kullanılan balta kelimesini diğerlerinden önce getirmiş ve balta ile ilgili genel bilgileri burada vermiştir. Baltanın tanımı; ă̆aç kesmeye, odun yarmaya, ağacı kaba saba yontup hazırlamaya yarayan alet şeklinde sıfat tamlaması grubu ile yapılmıştır. Sonra hiçbir açılıma yapılmadan aşağıdaki alıntı ile devam edilmiştir. ${ }^{8}$

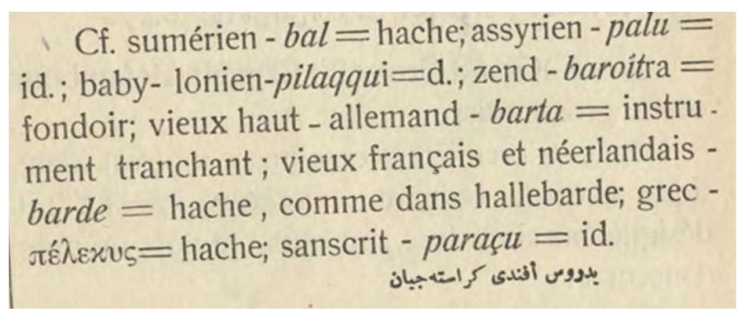

Tablo 2. TL'de Keresteciyan'dan yapılan alıntı

\footnotetext{
$7 \quad$ Buradaki çeviri yazı değerleri daha yerleşmemiş değerlerdir. Sonraki dönemlerde yavaş yavaş olgunlaştırılmıştır: $s$ harfi > “-y-" TL = "-1-,-i-" TT; ๔ harfi > "tch" TL = "ç" TT; ش harfi > "ch" TL = "ş" TT gibi. Bazi Arap harflerinin eserdeki çeviri yazıları su andaki gibi b harfi > "t" $T L=$ "t" TT seklinde iken ق harfi "k" $T L=$ "k" TT ve $\dot{\varepsilon}$ harfi “g” $T L=$ " $\mathrm{g}$ ” TT şeklindedir. Görüldüğg̈ gibi mütercimin kullandığı çeviri yazı günümüzün çeviri yazılarından farklıdır.

$8 \quad$ Metinde şiirlerden ve nesirlerden alınan hiçbir örnek açıklanmamıştır.

RumeliDE Dil ve Edebiyat Araşttrmaları Dergisi $\quad$ RumeliDE Journal of Language and Literature Studies Osmanağa Mahallesi, Mürver Cicçeği Sokak, No:14/8 Osmanağa Mahallesi, Mürver Çiçeği Sokak, No:14/8 Kadıköy - İSTANBUL / TÜRKIYE 34714 Kadıköy - ISTANBUL / TURKEY 34714 e-posta: editor@rumelide.com $\quad$ e-mail: editor@rumelide.com, tel: +90 $5057958124,+90216773$ o 616 phone: +90 505 7958124, +90 2167730616
} 
Alıntıdan sonra kelimenin yer aldığı söz grupları alt başlıklarda toplanmıştır. İlk önce darb-ı meseller başlı̆̆ı atılmış, darb-ı mesellere ait tanıklar hep cümle halinde yazılmıştır:

- Balta degmedik ă̆aç olmaz.

- Baltayı asdı.

- Baltayı taşa vurdı.

Darb-ı mesellerden sonra özel anlam kazanan birleşik yapılar (isim ve sıfat tamlaması) iç madde olarak alınıp tanımları yine isim veya sıfat tamlaması ile yapılmıştır:

gönderli balta - Eskiden padişahın atının etrafinda giden beglerin taşıdıkları teber.

balta baş - Düz başlı gemi.

Balta kelimesi gerçek anlamını kaybetmeden bazı isimlerle kalıcı isimler, terimler oluşturmuşsa sadece sıralama yapılmıştır:

balta sapı; eger baltası; hacamat baltası ...

Fiille biten deyimlerin sonu isim fiil -mAk eki ile yazılmış, kısaltma yapılmaksızın -mecazen- terimi ile etiketlenerek anlambilime gönderme yapılmış ve deyimin tanımının sonu yine isim fiil ekiyle bitirilmiştir:

balta asmak - mecazen - musallat ve bela olmak.

baltaya sap olmak - mecazen - iş ve meslek sahibi olmak.

balta görmemiş - mecazen - haliyle burakılmış ve kesilmemiş orman.

balta girmemiş - bakınız - balta görmemiş

baltayı taşa vurmak -mecazen- bilmeksizin ve farkında olmaksızın birinin yüzüne karşı dokunacak söz söylemek, pot kırmak.

Sadece balta asmak deyiminde tanık sunulmuştur. Tanıklamada üç tanıktan ikisi balta asmak deyimini içerirken bir örnek balta-zen kelimesini içerir. Burada madde-tanık uyumsuzluğu oluşmuştur.

Madde başı balta kelimesinin alt maddeleri, türemiş olan baltacı; baltalu, baltali; baltalık; baltalamak kelimelerinin anlamları verilerek bitirilmiştir.

Balta madde başı karşımıza Çağatay balta, balto; Azeri, balta ve Uygur balto kelimeleri olarak tekrar çlkar. Ancak madde başı olan Çağatay dilinin ara maddesi olarak Çuvaş, Altay ve Koybal dilleri yazılmıştır. Bu dillerde balta kelimesinin karşılığı olarak farklı kelimeler yazılmıştır. Koybal dilinde ise balta - balta şeklinde ekleme yapılmıştır:

$$
\begin{aligned}
& \text { balta, balto - Çaǵatay - isim - balta. } \\
& \text { Ay balto - ay balta - teber. } \\
& \text { Çuvaş - Vala - bölünmüşşey - parça. } \\
& \text { Vala-yas - bölmek - parçalamak } \\
& \text { pöl [ö] - Bölmek, ayırmak. } \\
& \text { Altay - pöl - Bölmek }
\end{aligned}
$$

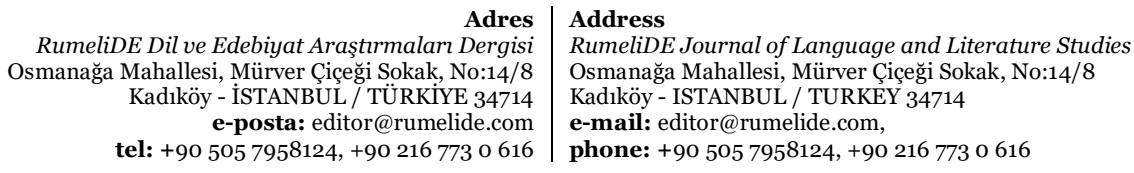




$$
\begin{aligned}
& \text { pölgüş - parça } \\
& \text { Koybal - balak-yara. } \\
& \text { balta - balta } \\
& \text { - Bir bahane bilen şehrde kaldı dahı balto alıp küffarning putların uşattı. Tarih-i Enbiya } \\
& \text { - Fazıl Tarhannı bir nice nökeri bile çapkulap olturup dervazenin kuflın balto bile çapıp } \\
& \text { dervazeni açtılar Babür-name } \\
& \text { Balta - Azeri - isim - balta } \\
& \text { baltalamak - baltalamak } \\
& \text { Kurtarup liki işin } \\
& \text { Sazladı balta dişin Şayık-Talib-zade } \\
& \text { balto - Uyg்ur - isim - balta. }
\end{aligned}
$$

Bu madde başlarından sonra ț ile yazılan bir balta kelimesi iki sayfa sonra karşımıza çıkar (TL I, s. 634). Kazan dili olduğu ifade edilen bu madde, yukarıdaki Çağatay dilindeki Ay balța - Ay balta, teber açılkaması ve Garb dilindeki balța sapı - balta sapı, hacamat baltası, balțacı - baltacı açıklamasının tekrarı bir de Farsça sözlükten alınan teber-dar kelimesi ile anlamlandırılmıştır:

$$
\begin{aligned}
& \text { balța-Kazan-isim-Balta. } \\
& \text { Ay balța-Ay balta, teber. } \\
& \text { Balța sapı-balta sapı. } \\
& \text { Hacamat baltası } \\
& \text { Balțacı-baltacı, teber-dar. }
\end{aligned}
$$

\section{Türk Lügatinde balta madde başı düzeninin değerlendirilmesi}

1. TL’de be maddesinde aynı anlama gelen kelimeler sirasıla بالتو ، بالتا [balta] Garb ، بالطه ، بالطا ، بالتا [balta, balto] Çağatay, بالتا [balta] Azeri ve بالتو [balto] Uygur (TL, s. 632) ve balța Kazan (TL, s. 634) şeklinde farklı beş madde başı yapılmıştır.

2. Mütercim, TL'de Garb Türkçesinde kullanılan balta kelimesini diğerlerinden önce getirmiş ve balta ile ilgili genel bilgileri burada vermiştir.

3. Balta'nın tanımında ağaç, odun ve alet isimlerinden; kesmek, yarmak, yontmak, hazırlamak ve yaramak fiillerinden; kaba saba zarf kelime türünden faydalanılmıştır. Baltanın tanımı ise, sıfat tamlaması grubudur.

4. Tanıklamaların hiçbirinde açıklama yapılmamıştır.

5. Alt maddeler ise; darb-ı meseller, özel anlam kazanan birleşik yapılar, kelimelerin gerçek anlamını kaybetmeden oluşturduğu birleşik isimler, deyimler ve türemiş kelimelerdir.

6. Madde başı balta Garb diliyle sözlük birim olarak açıklandıktan sonra karşımıza Türk lehçeleri dilleriyle (Çağatay balta, balto; Azeri, balta ve Uygur balto) olarak tekrar çıar.

7. Çağatay dili; Çuvaş, Altay ve Koybal dillerini alt maddede toplamıştır.

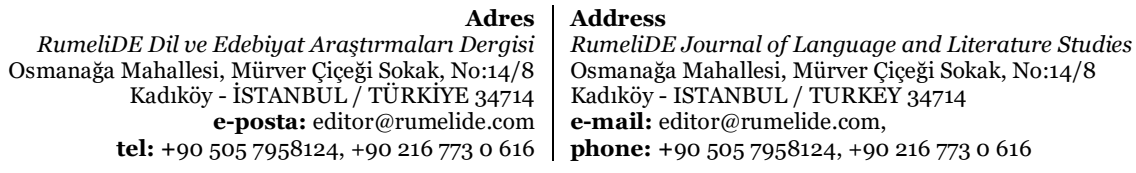


8. ț ile yazılan bir başka balta kelimesi, iki sayfa sonra tekrar madde başı yapılır. Kazan dili olduğu ifade edilen bu madde başının Garb ve Çağatay dilindeki açıklamalarına yalnız Farsça eşanlamlı bir kelime eklenmiştir.

\section{TL'deki madde başı balta'nın içerikleri}

\begin{tabular}{|c|c|c|c|c|}
\hline Madde başı & Dili & $\begin{array}{l}\text { Kelime } \\
\text { türüi }\end{array}$ & Anlamı & Madde içi muhtevası \\
\hline بالطه ، بالطا ، بالتا & Garb & isim & tanımı & $\begin{array}{l}\text { Keresteciyan / } 3 \text { darb-ı mesel / } 2 \text { i. taml. ve } 2 \\
\text { sf. taml. / } 4 \text { Mecazlı deyim / } 4 \text { türemiş kelime }\end{array}$ \\
\hline $\begin{array}{l}\text { بالتو ، بالتا } \\
\text { [balta, balto] }\end{array}$ & Çagatay & isim & balta & ay balto "ay balta, teber" \\
\hline- & Çuvaş & - & - & $\begin{array}{l}\text { vala: bölünmüş şey, parça. } \\
\text { Valayas: bölmek, parçalamak } \\
\text { pul: bölmek, ayırmak }\end{array}$ \\
\hline- & Altay & - & - & $\begin{array}{l}\text { pöl: bölmek } \\
\text { pölgüş: parça }\end{array}$ \\
\hline- & Koybal & balta & balta & $\begin{array}{l}\text { balak: yara // balta: balta } \\
1 \text { Tarih-i Enbiya ve } 1 \text { Babür-name örneği }\end{array}$ \\
\hline ] بالتا & Azeri & isim & balta & $\begin{array}{l}\text { baltalamak - baltalamak // 1. Tanık: Şayık } 2 . \\
\text { Tanık: Talib-zade }\end{array}$ \\
\hline [balto] بالتو & Uygur & isim & balta & - \\
\hline balța & Kazan & isim & balta & $\begin{array}{l}\text { Ay balța - Ay balta, teber. // Balța sapı - balta } \\
\text { sapı. Hacamat baltası // Balțacı - baltacı, } \\
\text { teberdar. }\end{array}$ \\
\hline
\end{tabular}

Tablo 3. TL'de balta kelimesi ve içerikleri.

c. Sözlük maddesi bağlamında Türk Lügatinin genel sözlüklerden farkı

a. Genel sözlüklerde madde başları ve ara maddeler alfabetik düzene göre hazırlanırken TL’nin ara maddeleri belli terimlere göre düzenlenmiştir.

b. Lehçelerde yer alan herhangi bir kelimenin farklı farklı madde başı olarak alınması genel sözlüklerde olmayan bir durumdur.

c. Genel sözlüklerde kısaltmalarla çapraz gönderim yapılırken $T L$ 'de kısaltma yapılmadan gönderim yapılmaktadır. balta başı alt maddesinde $b a$. ile baş kelimesine çapraz gönderme yapılmış, anlam yazılmamıştır. TL'de; inābet [inābét] - Kazan - 'Arapça - isim - me'meniyyet, i timad, inan. Bakınzz işanç (TL I, s. 303) şeklinde inâbet kelimesinin Arapçadan alınıp Kazan dilinde kullanıldığı belirtilirken karşılığı Garb Türkçesiyle ifade edilmiştir. Kazan diliyle karşılığı olan işanç kelimesine bakınız etiketiyle gönderme yapılmıştır (TL I, s. 240). Gönderme bazen de bir etiketle iki dile yapılabilmektedir: utmak [outmak] - Azeri - Bakınz - yutmak, udmak gibi. Anlam verilmeden kelime Garb Türkçesi ve Azeri Türkçesine gönderilmiştir.

d. Madde başının tanımı yapılırken genel sözlüklerde yapılan tanımlar gibi yapılmıştır.

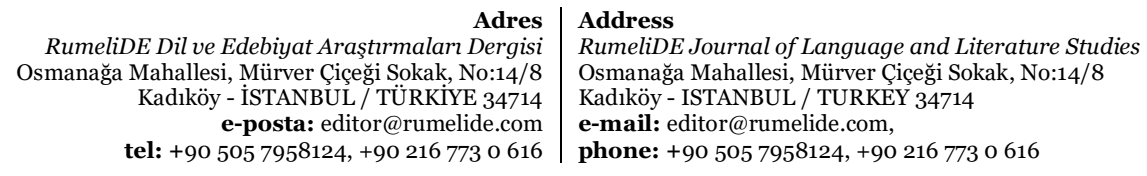


e. Genel sözlüklerde lehçeler bulunmazken $T L$ 'de aynı madde başı farklı lehçelere göre tekrar yazılmıştır.

f. Genel sözlüklerde yabancı dillerden geçen cümlelerin anlamı Allahualem "Tanrı en iyisini bilir" anlamında bir söz (TDK, 2010, s. 101) veya inşallah "Tanrı dilerse, Tanrı nasip ettiyse” (TDK, s. 1198) şeklinde karşılıkları verilmektedir. $T L$ 'de ise hiçbir yabancı yapının anlamı verilmemiştir.

g. Türemiş kelimeler genel sözlüklerde madde başı olurken $T L$ 'de, iştikaki sözlüklerdeki gibi madde içi olarak verilmiştir.

\section{C.2. TL ile lehçebilim sözlük örneği $D S, K T L S$ ve TDES'nin sözlük birim bakımından karşılaştırılması}

Lehçebilim sözlüğü (dictionnaires dialectologiques, dialectological dictionaries, dialektologische Wörterbücher) belli bir lehçedeki veya ağızdaki sözvarlıklarını ele alan sözlüklerdir. TDK’nin Derleme Sözlüğü gibi (Aksan III, 2009, s. 79). Lehçe, ağız ve şive terimleri daima birbiriyle karıştırılmakta, bazen aynı anlamda, bazen de farklı anlamlarda kullanılmaktadır. Lehçebilim sözlüğü olan $D S$ 'de farklı yazılan her kelime madde başı yapılıp anlamı, kullanıldığı metin ve bölge belirtilmektedir. Farklı devletlerin kullandığı Türkçenin her biri için Türk lehçeleri terimi kullanılmaktadır. TL sözlüğündeki sözlük maddeleri Azerbaycan Türkçesi, Türkmenistan Türkçesi, Kazan Türkçesi vb. Türkçelere göre düzenlenerek “Türk Lehçeleri Sözlüğü” hazırlanabilir. $D S$ 'deki gibi Türkçe kabul edilen kelimeler madde başı yapılabilir, tanığı ve konuşulduğu alan/bölge/lehçe yazılabilir.

TL'de aynı anlamdaki kelime farklı lehçelere göre ayrı ayrı madde başı olarak verilmiştir. Kadrînnin lehçeler sözlüğü bağlamında örnek bir modeli yoktu. $K T$ ve diğer sözlükler, eski metinlerdeki Türkçe kelimelere Uygur dilinden, Çağatay Han'dan sonra Çağatay dilinden veya Şark Türkçesinden etiketiyle ifade ediyordu. Kadrînnin birbirinden ayrı düşmüş kavimlerin farklı söyleyişlerini bir araya getirme çabası, sözlük tanıklarının kuramsal sözlükbilimi çalışmalarına uygun işlenebilmesi için yeterli olmamıştır. Sözlükte yanlış kelimelerin bulunması ve sözlük hazırlama çalışmasında beklenen yardımların alınamaması, $T L$ 'nin sözlükbilimi açısından tenkitlere maruz kalmasına ve sözlüğün bilim âleminde gerçek yerini alamamasına neden olmuştur. Köprülü, Bedros Keresteciyan'ın; Eren ise, İsmet Zeki Eyyuboğlu ve Vambery'nin sözlük hazırlarken dilin fonetik, morfolojik ve semantik usullerine dikkat etmediklerini, emeklerinin boşa gittiğini ve çalışmalarının iflas ile neticelendiğini belirtirler (Eren, 1999, s. XI-XII). Ercilasun ise, Karşılaştırmalı Türk Lehçeleri Sözlüğü Üzerine isimli yazısında lehçe sözlükleri denemesinde Budagov ve Radloff'tan sonra, art zamanlı yöntemin kullanıldığı, çok ve çeşitli örneklerin sunulduğu TL’nin müellifi Kadrî̀yi de sayar (Ercilasun, 77-81).

Kadrînnin Türkiye Türkçesini Garb, diğer lehçeleri Azeri, Kazan, Altay, Koybal vb. şekilde farklı adlandırıp kullanması, sözlükbiliminin genel sözlük türüne uygun olmayan bir adlandırmadır. Bu diller farklı dil ise çokdilli sözlük hazırlanmalıdır. Eğer dillerin kelimeleri, aynı çatı altında değerlendirilmek isteniyorsa hem de tekdilli genel sözlük yapılmak isteniyorsa bir kelime madde başı olarak, diğerleri alt madde olarak eklenmelidir. Alt maddelerde değerlendirilen kelimeler, madde başı yapılacaksa çapraz gönderimlerle anlam yazılmadan -her ne kadar sakıncalı olsa da- sözlüğe yerleştirilmelidir.

Sözlükbiliminin kabul etmeyeceği bir uygulama kullanarak hacimli bir sözlük hazırlamaya çalışmak hatalı bir harekettir. Acaba yüz senedir bu sözlükten bahsedildiği hâlde hâlâ derli toplu bir basımı yapılamaması, Kadrî’nin emeklerinin boşa gittiği fikrinin doğru olduğunun göstergesi midir? Genel

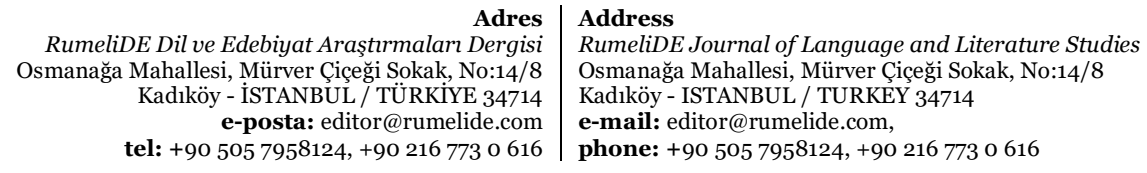


sözlük yerine lehçebilim sözlüğü hazırlama fikriyle yola çıkılmış olsaydı, bugün bir Kâmûs-i Türkî gibi genel sözlüğümüz olduğu gibi, bir de Türk Lügati isimli lehçeler sözlüğümüz mü olurdu?

Aşağıdaki bölümlerde Türk Lügati ile Derleme Sözlüğü, Karşılaştırmalı Türk Lehçeleri Sözlüğü ve Türk Dilinin Etimolojik Sözlüğü lehçebilim sözlüğ̈̈ açısından karşılaştırılmıştır. DS’deki kullanım alanı ağızlar ile lehçe sözlüklerindeki kullanım alanı devlet adlarının aynı görevde olduğu var sayılmıştır.

\section{a. DS'de balta ve eserli madde başları}

DS'de balta madde başının dört anlamı bulunmaktadır. Birinci anlamlı balta (I) ile baltackk ve dört kelime daha aynı anlamı taşımaktadır. Ağızlarda aynı anlama gelen farklı şekillerdeki kelimeleri barındıran birinci balta (I) ve bununla aynı anlama gelen baltacık, baltacık demiri, baltacuk, baltancı, baltancuk kelimelerinin sözlüğe nasıl yerleştirildiğini görelim:

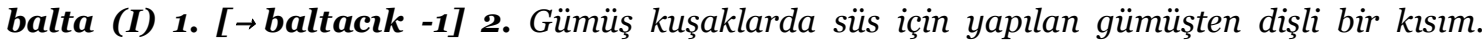
(Beypazarl-An.) (DS, s. 511).

Madde başı olan balta kelimesinin iki anlamından birincisinin anlamının baltacık madde başında verildiğini ifade eden gönderme vardır. O hâlde balta ve baltackk aynı anlamda kullanılmıştır ve anlamını öğrenmek için baltacık kelimesine gidelim:

baltacık [balta (I) - 1, baltacık demiri, baltacuk, baltancık, baltancuk] 1. Değirmen taşının ortasında bulunan ve onu döndüren demir, haç şeklindeki aygıt. (Isp., Kü., Bo., vb. 17 şehir). (DS, s. 512).

İlk kelime madde başı baltacık kelimesiyle aynı anlamda kullanılan beş madde başı kelime olduğu ve kelimenin 17 şehirde tanığı olduğu anlaşılır. Sonra baltacık kelimesine yapılan alt madde kelimeler biraz içeriden tanıklarıyla alfabetik olarak sıralanır:

[balta (I) -1]: (15 şehir adı)

[baltacık demiri]: (1 şehir adı).

[baltacuk]: (7 şehir adı).

[baltancık]: (2 şehir adı).

[baltancuk]: (Tr.). gibi.

Bu ara maddeler $D S$ 'de alfabetik sırasında da madde başı yapılmış, aşağıdaki şekilde anlam yazılmadan madde başı ve anlam numarasına çapraz gönderimde bulunulmuştur:

\section{baltacık demiri [ $\rightarrow$ baltacık -1$]$}

baltacuk [ $\rightarrow$ baltackk -1]

baltancık [ $\rightarrow$ baltacık -1]

baltancuk $[\rightarrow$ baltackk -1$]$ gibi.

$D S$ 'den sunulan ikinci örnek eserli kelimesi, eserli (I) ve eserli (II) şeklinde farklı anlamlarıyla iki madde başı yapılmıştır. Birinci madde başındaki 6 kelimenin aynı zamanda sözlükte alfabetik sırasında bulunduğu, fakat anlamının ve tanığının eserli (I)'de verildiği anlaşılır. Madde başındaki ilk kelimeden sonraki kelimeler alt madde olarak alınıp tanıkları verilmiş, sonra bu alt maddeler alfabetik sırada madde başı yapılıp sadece gönderme yapılmıştır.

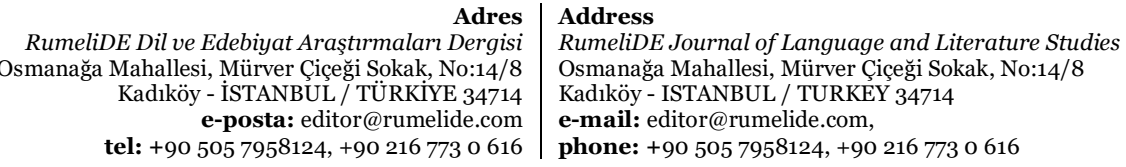

Address

RumeliDE Journal of Language and Literature Studies

Osmanağa Mahallesi, Mürver Çiçeği Sokak, No:14/8

Kadıköy - ISTANBUL / TURKEY 34714

e-mail: editor@rumelide.com,

phone: +90 505 7958124, +90 2167730616 
Sözlükte alfabetik olarak önce gelen madde başı eserik kelimesi alınmış, anlamı verilmeden gönderme yapılmıştır: eserik [ $\rightarrow$ eserli (I) -2] gibi. Sonra anlamların verildiği eserli (I) madde başına geçilmiş ve diğerleri aşağıdaki gibi satır başı yapılarak biraz içeriden yazılmıştır:

eserli (I) [eserik, eserük -1, eserüklü, esirek -2, esirik -2] 1. Delişmen, deli. (Isp., Brd., Dz., 16 il) 9 .

[eserük -1]: Ks.

[eserüklü]: Gm. 2. Sarhoş. (Es.)

[eserik]: (Isp.).

[esirek -2]: (Isp.)

[esirik -2]: (Bo., Kırım Türkleri -İst.) 3. Sar’alı olan(kimse). (İz., Zn., Sv., Kn., İç.) 4. Herhangi bir tarafına inme inen (kimse). (Dz.).

eserli (II) Gösterişli. (Hat.) (DS, s. 1780) şeklinde tamamlanmıştır.

Sonra anlamlar aynı ise alt maddeler, tek tek madde başı yapılarak sadece eserli (I)'e gönderme ile yetinilmiştir:

eserük 1. [ $\rightarrow$ eserli (I) -1] 2. Herhangi bir hastalıktan kalan iz. (Sv.)

eserüklü [ $\rightarrow$ eserli (I) -2] (DS, s. 1780).

esirek 1. Herhangi bir nedenle kendinden geçmiş, esrik. (Isp.) 2. [ $\rightarrow$ eserli (I) -2] (DS, s. 1782).

esirik [esirikli, esürük -1] 1. ... 2. [eserli (I) -2] 3 … 4 … (DS, s. 1783) gibi.

$D S$ bu iki örnek kelimenin farklı şekillerini, anlamlarını, kullanıldı $\breve{ı}$ bölgeleri bir sistem dahilinde sunmaktadır. Anlamı kendisinde verilmeyen fakat başka kelimelerle şekil, anlam ve alan paydaşlı̆ı̆ bulunan bir kelime, sözlükte madde başı olarak yer alır, irtibatlı olduğu kelimelerle münasebetinin anlaşılması için de sadece gönderme ile yetinilir. Lehçeler veya ağızlarda farklılık arz eden kelimeler TL'de de bu şekilde sistemle sunulursa aranan kelimeye kolayca erişilebilir, kelimenin fonetik, morfolojik ve semantik özellikleri ve ilişkileri karşlaştırılabilir. Türk lehçelerinin vahdeti daha kolay sağlanabilir.

\section{b. KTLS'de balta, balçık ve baldız madde başları}

Lehçebilim özelliği taşıyan Karş̧laştırmah Türk Lehçeleri Sözlüğündeki balta, balçık ve baldız kelimelerine (KTLS, s. 48-49) göz atalım: İki cilt halinde hazırlanan sözlüğün birinci cildinde 7000 Türkçe kelimenin 9 farklı Türk lehçesine göre karşılığı yazılmıştır. İkinci cildinde ise her dilin kendi sözlüğü yapılarak birinci büyük/kılavuz cilde gönderme yapılmıştır. Eser, tercümede ve pratik konuşmalarda yardımcı olmak amacıyla hazırlanmıştır. Eşanlamlılık bağlamında Türkçe ve Rusça ile birlikte 10 dilin kelimeleri bir araya getirilmiştir. Örnek olarak balta kelimesini alalım:

Türkiye Türkçesi: balta |Azeri Türkçesi: balta | Başkurt Türkçesi: balta |Kazak Türkçesi: balta | Kirgız Türkçesi: balta | Özbek Türkçesi: bàltä | Tatar Türkçesi: balta | Türkmen Türkçesi: palta | Uygur Türkçesi: palta | Rusça: topór (Ercilasun, 1992, s. 48-49) gibi.

Bu lehçebilim sözlüğünde balta kelimesi TT’ne göre hazırlanmıştır. TT lehçesini kullanan için kolay kullanımlı bir lehçebilim sözlüğüdür. Dizin kısmını kullanmaya gerek kalmamaktadırr. Fakat diğer

$9 \quad$ DS deki parantez içindeki kısaltmalar şehir adlarının kısaltmalarıdır.

Adres | Address

RumeliDE Dil ve Edebiyat Araştırmaları Dergisi $\quad$ RumeliDE Journal of Language and Literature Studies

Osmanağa Mahallesi, Mürver Çiçeği Sokak, No:14/8 $\quad$ Osmanağa Mahallesi, Mürver Çiçeği Sokak, No:14/8

Kadıköy - ISTANBUL / TURKIYE 34714 Kadıköy - ISTANBUL / TURKEY 34714

e-posta: editor@rumelide.com $\quad$ e-mail: editor@rumelide.com,

tel: +90 505 7958124, +90 216773 o 616 phone: +90 505 7958124, +90 216773 o 616 
lehçelerin sözlük kullanıcısı sözlüğün II. cildinde kendi lehçesindeki kelimeyi ve karşısında yazan sayfa numarasını tespit edecek, sonra kılavuz kitaptaki sayfayı, kelimeyi, anlamı ve farklı şekilleri görebilecektir. Lehçeler bakımından inceleme yapan kişi kelimenin üç farklı şekline zahmetsizce ulaşacaktır: "balta, bàltä, palta"

Sözlük hazırlayıcısı burada yer alan lehçeleri kullanan kişilere amacı doğrultusunda hizmet etmiştir. Kitabın hazırlanmasında birinci amacı lehçebilim sözlüğü hazırlamak olsaydı, herhâlde farklı şekli kullanırdı. Ercilasun, sonraki lehçebilim sözlüğü hazırlama çalışmalarında sözlük uygulamalarıyla ilgili bilgiler sunmuştur (Ercilasun, 1999, s. 80).

Türkiye Türkçesine göre alfabetik dizilen I. cilt/kılavuz kitapta balçık kelimesi lehçelerde 8 farklı madde başı olacak şekilde yazılmıştır: Türkiye Türkçesi: balçık | Azeri Türkçesi: palçıg | Başkurt Türkçesi: balsık | Kazak Türkçesi: balşık | Kırgız Türkçesi: balçık batkak| Özbek Türkçesi: balçık | Tatar Türkçesi: balçık sutlı balçı | Türkmen Türkçesi: palçık | Uygur Türkçesi: lay patkak balçık | Rusça: glina (Ercilasun, 1992, s. 48-49).

baldız kelimesi ise, lehçebilim sözlüğünde 7 madde başı olacak şekilde kullanılmıştır: Türkiye Türkçesi: baldız |Azeri Türkçesi: baldız |Başkurt Türkçesi: käyinbikä baldı $\square$ |Kazak Türkçesi: baldız |Krrgız Türkçesi: kayın ece baldız |Özbek Türkçesi: bàldiz |Tatar Türkçesi: kaynigäç baldız | Türkmen Türkçesi: özayãlıĐıy ayãl doğanı | Uygur Türkçesi: keyin egiçä ḳeyin sinil | Rusça: svoyaçenitsa gibi (Ercilasun, 1992, s. 48-49).

Kitaptan kitaba göndermeli olan bu sözlükte, lehçebilim kuramları uygulamasına göre ana madde başı kelimede anlamlar sunulması ve diğer madde başlarında o kelimeye gönderme yapılması gerekirdi. Lehçebilim sözlüğü kullanıcısı için kullanım kolaylı̆̆ı olmadığı hâlde $K T L S$ de aranan kelimeler ve aldıkları farklı şekiller sözlükbilimine uygun olarak bulunabilmektedir.

\section{c. TDES' de balta madde başı}

Eren’in sözlüğünde balta maddesinin 22 lehçede geçen 7 varyantı yazılıdır. TL ile kesişen nokta sadece Çuvaş, Altay ve Koybalca dilidir. Eren, balta kelimesinin farklı dillerdeki anlamını, balta ile ilintili kelimelerin de balta ile ses benzerliğini ve bağlantısını inceleyen yirmi kadar araştırmacının değerlendirmesini özetleyerek maddeyi tanıtır (Eren, 1999, s. 37-38). Eren’in sözlüğü etimolojik sözlük olduğundan lehçebilimle ilgili başta bilgiler verilmiş, sonra kelimenin fonetik, morfolojik ve semantik incelemeleri ve araştırmacıların görüşleri tenkitli açıklanmıştır. Bu sözlük lehçebilim sözlüğü bağlamında değerlendirildiğinde balta maddesinin birinci kısmı yeterli olurdu. Lehçelerden herhangi birini inceleyen sözlük kullanıcısı, aradığı kelime 22 lehçede tespit edilen ve madde başı yapılan yedi varyanttan biri ise aradığı kelimeyi bulabilir.

\section{d. TL'nin sözlük birim tablosu ve lehçebilim sözlüklerine göre sözlük birim düzenleme denemesi}

$D S, K T L S$ ve TDES yukarıda yer alan kelimeler bağlamında lehçebilim açısından değerlendirildikten sonra balçık, baldız ve balta kelimelerini $T L$ 'de inceleyelim. Kelimeleri tablo içinde gösterelim. $D S$ 'ye göre alabileceğini düşündüğümüz şekli hemen altında verelim. $T L$ 'de madde başlarının düzeni tanıklar gösterilmeden yapılmıştır. Şayet tanıklar belirtilecekse lehçe adından önce yazılabilir.

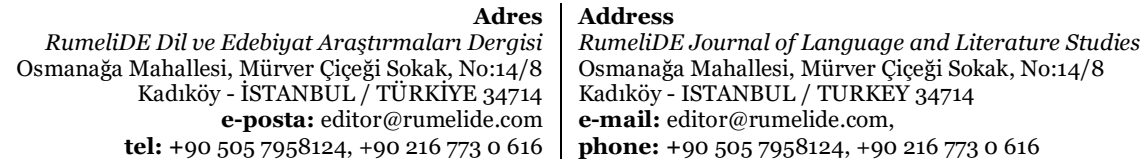




\begin{tabular}{|c|c|c|c|c|}
\hline Madde başı & Lehçe & Türü & Tanımı & Madde içeriği \\
\hline $\begin{array}{l}\text { بالِيق , بالجق } \\
\text { [baltchyk] }\end{array}$ & Garb & isim & 3 sf. taml. & $\begin{array}{l}\text { balçıklı // balçılanmak // Tanık: } \\
\text { Keresteciyan }\end{array}$ \\
\hline [baltchyk] بالجق ] & Kazan & isim & $\begin{array}{l}1 \text { sf. taml. ve } \\
\text { balçılk }\end{array}$ & $\begin{array}{l}2 \text { örnek ve kerpiç balçıgı, balçılklı, } \\
\text { balçıllanmak // bakınız: beliçraḳ (TL I, s. } \\
633 \text { ) }\end{array}$ \\
\hline $\begin{array}{l}\text { بالجيق , بالجيغ } \\
\text { [baltchyg, baltchyk] }\end{array}$ & Çağatay & isim & $\begin{array}{l}1 \text { sf. taml. ve } \\
\text { balçık }\end{array}$ & Nevayi’den 3 örnek \\
\hline
\end{tabular}

Tablo 4. TL I, s. 632-633: balçık maddesi.

\section{Lehçebilim sözlüğüne göre balçık madde başı denemesi}

balçı̀ $[\rightarrow$ balçı̣] $]$.

balçı̣ [balçı̇̉] Ayağa yapışan çamur, özlü ve yaş toprak, killi toprak. (Garb, Kazan, Çağatay).

balçıg̀ (Çağatay)

balçıł̣lanmak [beliçramaḳ] Balçık halini almak, balçık ve çamur dolmak, millenmek. (Garb, Kazan).

beliçramaḳ (Kazan)

balçıḳı Çamurlu (Garb, Kazan)

beliçramaḳ [ $\rightarrow$ balçı̣̣lanmaḳ]

çölmek balçı̀̀ı (Kazan)

kerpiç balçı̀̆ı (Kazan)

özlü balçı̣̣ (Kazan)

yapuşḳan balçı̣̣ (Kazan)

\section{TL'de baldız madde başı}

\begin{tabular}{|c|c|c|c|c|}
\hline Madde başı & Lehçesi & Türü & Tanımı & Madde içeriği \\
\hline $\begin{array}{l}\text { بالدز , بالديز } \\
\text { [baldyz] }\end{array}$ & Azeri & isim & baldız & $\begin{array}{l}1 \text { darb-1 mesel } \\
\text { Göçerli'den }\end{array}$ \\
\hline $\begin{array}{l}\text { [baldyz, baldouz] بالدز بالدوز } \\
\text { [الداز }\end{array}$ & Çağatay & isim & baldız & \\
\hline $\begin{array}{l}\text { بالاز , بالديز } \\
\text { [baldyz] }\end{array}$ & Kazan & isim & i. taml. ve baldiz & Halksözleri'nden \\
\hline [الديز [baldyz] & Garb & isim & i. taml. & \multirow{2}{*}{$\begin{array}{l}\text { ba. baldyz (Azeri } \\
\text { Çağatay ve Kazan } \\
\text { dilindeki yazım) }\end{array}$} \\
\hline [الديز [baldyz] & Kazan & isim & i. taml. & \\
\hline
\end{tabular}

Tablo 5. TL I, s. 633-634: baldız maddesi.

\section{Lehçebilim sözlüğüne göre baldız madde başı denemesi}

baldouz $[\rightarrow$ baldyz $]$

baldyz [baldouz, ḳayın sinil] Zevcenin küçük kzz kardeşi, baldız (Azeri, Çağatay, Kazan, Garb, Kazan)

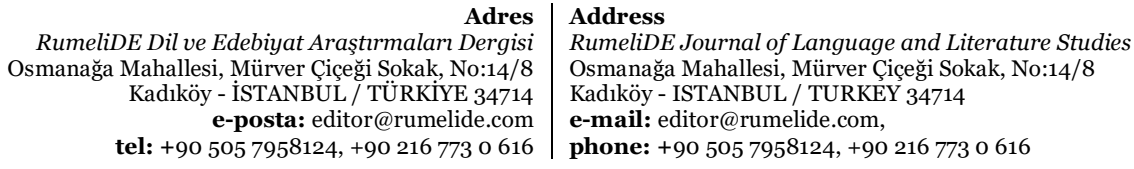




\section{baldouz (Çă̆atay) \\ kayın siyil (Kazan)}

kayın siyil $[\rightarrow$ baldyz]

\section{TL'de balta madde başı}

\begin{tabular}{|c|c|c|c|c|}
\hline Madde başı & Lehçe & $\begin{array}{l}\text { Kelime } \\
\text { türüi }\end{array}$ & Anlamı & Madde içeriği \\
\hline 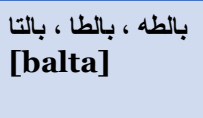 & Garb & isim & tanımı & $\begin{array}{l}\text { Keresteciyan / } 3 \text { darb-ı mesel / } 2 \text { i. taml. ve } 2 \text { sf. } \\
\text { taml. / } 4 \text { Mecazlı deyim / } 4 \text { türemiş kelime / bir } \\
\text { deyim }\end{array}$ \\
\hline $\begin{array}{l}\text { بالتو ، بالتا } \\
\text { [balta, } \\
\text { balto] }\end{array}$ & Çagatay & isim & balta & ay balto "ay balta, teber" \\
\hline- & Çağatay/Çuvaş & - & - & $\begin{array}{l}\text { vala: bölünmüşs şey, parça. // Valayas: bölmek, } \\
\text { parçalamak // pul: bölmek, ayırmak }\end{array}$ \\
\hline- & Çağatay/Altay & - & - & pöl: bölmek // pölgüş: parça \\
\hline- & Çağatay/Koybal & balta & balta & $\begin{array}{l}\text { balak: yara // balta: balta // } 1 \text { Tarih-i Enbiya ve } 1 \\
\text { Babür-name örneği }\end{array}$ \\
\hline بالتا & Azeri & isim & balta & $\begin{array}{l}\text { baltalamak - baltalamak // 1. Tanık: Şayık // } 2 . \\
\text { Tanık: Talib-zade }\end{array}$ \\
\hline [balto] بالتو & Uyg்ur & isim & balta & - \\
\hline balța & Kazan & isim & balta & $\begin{array}{l}\text { Ay balța - Ay balta, teber. // Balța sapı - balta } \\
\text { sapı. // Hacamat baltası // Balțacı - baltacı, } \\
\text { teberdar. }\end{array}$ \\
\hline
\end{tabular}

Tablo 6. TL I, s. 632-634: balta maddesi.

\section{Lehçebilim Sözlüğüne göre balta madde başı denemesi}

ay balta Ay balta, teber. (Çağatay, Kazan)

balak Yara (Koybal)

balta [balța, balto] Ağaç kesmeye, odun yarmaya, ağacı kaba saba yontup hazırlamaya yarayan alet. (Garb, Çağatay, Koybal, Azeri, Kazan)

balto (Uygur)

balta baş Düz başlı gemi (Garb)

baltacı 1. Eskiden saraylar haremde muhafızlarına verilen isim, teberdar (Garb) 2. Baltacı, teberdar (Kazan)

baltalamak 1. Balta ile vurup kesmek (Garb, Azeri) 2. mecazen Yıkıp harap etmek (Garb)

baltalı [baltalu] Askerde yol açan güruh, müsellem (Garb)

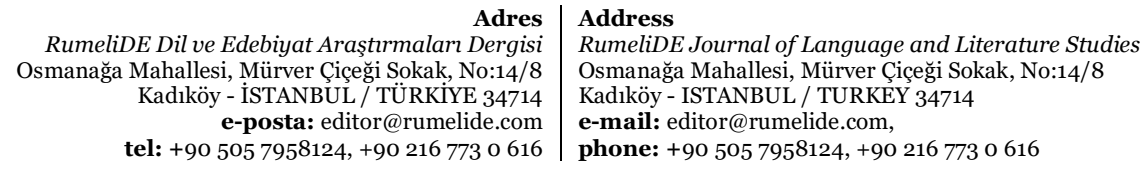


baltalık Bir köye tahsis edilen orman (Garb)

\section{baltalu [ $\rightarrow$ baltalı]}

balta sapı Balta sapı (Garb, Kazan)

\section{balto $[\rightarrow$ balta $]$}

eger baltası (Garb)

gönderli balta Eskiden padişahın atının etrafında giden beglerin taşıdıkları teber (Garb)

hacamat baltası (Garb, Kazan)

pöl Bölmek, ayırmak. (Çuvaş, Altay)

pölgüş Parça (Altay)

vala Bölünmüşs şey, parça (Çuvaş)

valayas Bölmek, parçalamak (Çuvaş)

Yukarıdaki örnekleri $T L, D S, K T L S$ ve TDES’ye göre sadeleştirerek tablolaştıracak olursak balta kelimesinin balta, balto, bàltä, palta ve purta şeklinde aynı anlama gelen beş varyantı olduğu görülür.

\begin{tabular}{|c|c|c|c|}
\hline Dili & $T L$ & TDES & KTLS \\
\hline Garb & ] [balta] بالطه ، بالطا ، بالتا & balta & balta \\
\hline Çagatay & [balta, balto] بالتو ، بالتا & - & - \\
\hline Çuvaş & - & purta [Eski Çuv. *balta] & - \\
\hline Altay & - & palta & - \\
\hline Koybal & - & palta & - \\
\hline Azeri & ] [balta] بالتا & - & balta \\
\hline Uyg்ur & [balto] & - & palta \\
\hline Kazan & balța & - & - \\
\hline Özbek & - & - & bàltä \\
\hline
\end{tabular}

Tablo 7. balta kelimesinin sözlüklerdeki varyantları.

Sonuç olarak yukarıdaki balçık, baldız ve balta kelimelerinde olduğu gibi aynı anlamlı ve varyantlı bir kelime için çok fazla tanık tutulması ve aynı ifadelerin tekrarı sözlük müellifinin amacına hizmet ederken sözlükbilimi açısından TL'nin değerini düşürmektedir. TL'deki tekrarları azaltan çalışmalarla sözlüğün değerli kısımları görünür hâle getirilebilirse, sözlük kullanıcılarına bir kolaylık sunulmuş olacaktır.

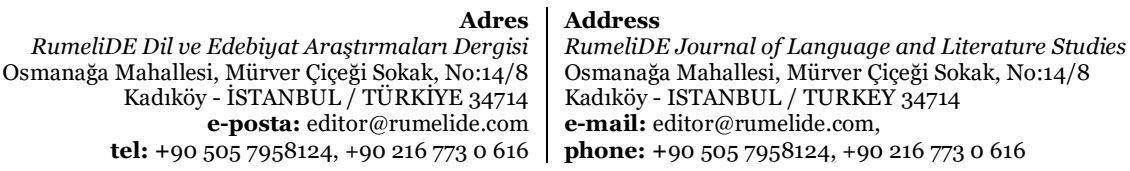




\section{C.3. TL ile Deyim ve Atasözleri Sözlüğğ’’nün ${ }^{10}$ sözlük birim bakımından karşılaştırılması}

Deyim ve atasözleri sözlükleri, dildeki sözvarlığının iyice bilinmesi ve dilbirliğinin, dünya görüşünün, değer yargılarının belirlenmesi için yapılan çalışmalardır. Türkçe Tabirler Sözlüğü (M. Nihat Özön) ve Atasözleri ve Deyimler Sözlüğü I-II “I: Atasözleri Sözlüğü; II: Deyimler Sözlüğ̈̈” (Ömer Asım AKSOY) gibi (Aksan, III, s. 82). Aksan'ın kitabını örnek gösterdiği Aksoy, Velet İzbudak’ın hazırladığı 1480 ylında yazılan Atalar Sözü ile başlayıp Şinasi'nin eseri ile devam ederek TL'yi içine aldığı on üç atasözleri ve deyimler kitabını tanıtır (Aksoy, 1993, s. 56-102). Milli Kütüphane Genel Müdürlüğünün yayınladığı Türk Atasözleri kitabı 10730 madde, Aksoy’un hazırladığı Atasözleri ve Deyimler Sözlüğü 8977 madde iken $T L$ 'de 6200 kadar madde olması bu sözlüğün Aksoy'un yaptı̆̆ gibi bizim de Atasözleri ve Deyimler Sözlükleri alanında değerlendirebileceğimizi gösterir.

Aksoy, TL'de 6200 kadar mesel ve atasözleri bulunduğunu belirttikten sonra üç açıdan eleştirir. 1 . Atasözü ve deyim olmayan sözleri örnek olarak sunmuştur: İki öküze bir saman verecek hâli yok / Bir bunda beni bir dahi mahşerde görürsün 2. Değiştirilerek yanlış verilen örnekler: Açma kutuyu söyletme kötüyü / Evladını döğmeyen sonra dizini döver 3. Doğru ve yanlış olarak iki şekilli verilen örnekler: Bir ayağı çukurda - İki ayağı çukurda / Bir çiçekle yaz olmaz - Bir bulutla kış olmaz (Aksoy 1993, s. 7274).

Yukarıda örnekleri sunulan balta, dil ve balık madde başlarında geçen darb-ı mesellerin bazıları Aksoy'un eserinde aynı, bazıları eksiltili, bazıları eklentili bulunur, bazıları ise hiç bulunmaz:

Farsça gönül anlamındaki dil ile ilgili sunulan darb-1 mesellerden ikisi; دل بدل راه دارد vل بردل كو اهى دهد ${ }^{11}$ Farsça, biri ise Dilde niyaz, elde piyaz (TL, II, s. 752) Türkçedir.

dilber alt maddesinde şu darb-1 meseller sunulur: Dilberde vefa olmaz, Dilberde vefa olmamak meseldir, Dilber kısmı gammazı sever, Dilbere dildâde sofiye seccâde aramılmaz (TL, I, s. 754).

dil-şikâf alt maddede bir Farsça darb-ı mesel vardır: دست شكسته كاركند، دلثكسته كار نمى كند (TL, II, s. 658). Burada bulunan gönül anlamı ile bağlantılı dil ve dilber ile ilgili deyimler veya atasözleri Aksoy'un sözlüğünde bulunmamaktadır.

delle - delâleten maddesindeki Delilsiz cennete bile girilmez (TL, II, s. 761; Aksoy, I: 232/No: 880) darb1 meseli her iki eserde aynı şeklini muhafaza eder.

TL'de balta maddesindeki mastar ekiyle biten ve mecazen etiketiyle açıklanan bu darb-ı mesellerin ( $T L$, I, s. 632) bazısı Aksoy'da aynı, bazısı farklı, bazısı da bulunmamaktadır:

Balta değmedik ağaç olmaz. (Aksoy, I, s. 179/No: 519) // Baltayı asdı (-) // Baltayı taşa vurdı. (-) // balta asmak (-) // Baltaya sap olmak [Bir baltaya sap olmak (Aksoy, II, s. 575/No: 3306)] // balta görmemiş: balta girmemiş [balta değmemiş (girmemiş, görmemiş) (Aksoy, II, s. 547/No: 3023)] // baltayı taşa vurmak (Aksoy, II, s. 547/No: 3025). // işe balta ile girişmek: baltalamadan gitmek (-).

balk maddesi ile ilgili darb-ı mesellerde de (TL, I, s. 636) durum aynıdır:

Ömer Asım Aksoy, Atasözleri ve Deyimler Sözlüğ̈̈ I, II.

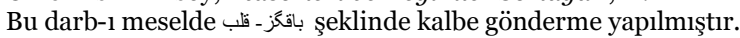

Adres Address

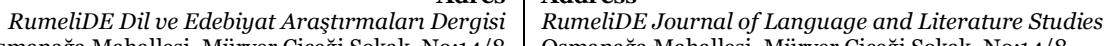
Osmanağa Mahallesi, Mürver Cicçeği Sokak, No:14/8 Osmanağa Mahallesi, Mürver Çiçeği Sokak, No:14/8 Kadıköy - İSTANBUL / TÜRKIYE 34714 Kadıköy - ISTANBUL / TURKEY 34714 e-posta: editor@rumelide.com $\quad$ e-mail: editor@rumelide.com, tel: +90 $5057958124,+90216773$ o 616 phone: +90 505 7958124, +90 216773 o 616 
Balık başdan avlantr (Aksoy, I, s. 178/No: 508) // Balık başdan kokar (Aksoy, I, s. 178/No: 509) // Balık kavağa çıkınca (Aksoy, II, s. 547/No: 3019) // Balık gibi birbirini yer (-) // Balık kılçı̆̆ıdır, boğazda kalır (-) // Balık gibi ele avuca girmez. [ele avuca siğmamak (Aksoy, II, s. 676/No: 4345)] // Bahı̆a saçma atmışlar, Buna başdan inme denir, demiş (-) // Denizde balık (Aksoy, II, s. 639/No: 3958).

İnsanların ağızlarında kaide-yi külliye şeklinde söylenen hikmetli sözleri darb-ı mesel kabul eden (Aksoy, I, s. 70) Kadrî, çizgileri çok hassas olan atasözleri ve deyimleri darb-ı meseller kısmında ele almıştır. Aksoy, TL'deki darb-ı mesellerin çokluğuna ve önemine dikkat çekmiştir. O hâlde $T L$ aynı zamanda atasözleri ve deyimler sözlüğü özelliğini de taşımaktadır diyebiliriz.

\section{C.4. TL ile eşadlı sözlük örneği Eser-i Şevketin sözlük birim bakımından karşılaştırılması}

Aksan, amacına ve niteligine göre sözlükler içinde yer alan ve anlamı ön planda tutan eşanlamlılar (sinonim), eşadlılar (homonim) ve tersanlamlılar (antonim) sözlüklerine Ağakay’ın Türkçede Yakın Anlaml Kelimeler Sözlüğünü gösterir (Aksan, III, s. 75; 79).

TL'de homonim sözlük özelliklerinin esintileri görülür. Aşağıdaki EŞ’nin madde başı örneklerinde eşyazımlılık dikkati çeker.

Herbir madde ayrı anlam taşımaktadır. Homonim sözlük özellikleri taşıyan bu sözlükteki gibi bazen Kadrî de bu türün özelliklerini uygulamaktadır:

\section{“Faṣlü'l-Ġayn Bi’ş-Şịn}

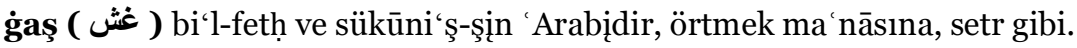

ġış ( غش ) bi'l-kesr 'Arabịdir, ḩıȳnet ètmek ve yaramazlıḳ olmaḳ ve șāfị olmayup ḳarışıḳ olmaḳ ma'nālarına.

gabeş ( غبش ) bi-fetḥateyn ‘Arabįdir, gėceniñ āḩirinde olan ḳarañulug̉a dẻnür ki yufḳa olur, cem i ag̉bāş gelür.

gabiş ( غبش ) ketif vezninde 'Arabįdir, pek ḳarañu gèceye dẻnür.

gaț̣ ( غطش ) bi-fetḥi'l-ġayn ve sükūni'ṭ-țầ' 'Arabịde gèce ḳarañu olmaḳ ma'nāsına.

gațaş ( غطش ) bi-fetḥateyn 'Arabįdir, göz şırılġanlu olmaḳ ma nāsına."

(EŞ, s. 510'den aktaran Ateş, 2017, s. 97).

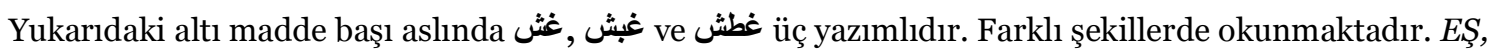
sözlüklerde madde başı olan kelimelerle aynı yazımlı olan fakat madde başı özelliklerini taşımayan çekimli fiiller, ek almış isimler vb. kelimeleri madde başı yapmıştır.

TL'de aşağıdaki örneklerde de yukarıdaki uygulamalar söz konusudur. TL'de dür (در) ve dil (دل ) madde başlarının iç maddelerinde kelimeler alfabetik dizilmemiştir. dürr kelimesinden sonra madde başı olarak derre ve derre'e kelimeleri; dil madde başından sonra madde başı delle, delāleten şeklinde Arapça lügat şekliyle gelmiştir. Bu kelimelerin etiketinde ise lugat yazmaktadır. Anlamlandırma

\footnotetext{
\begin{tabular}{r|l} 
Adres & Address \\
RumeliDE Dil ve Edebiyat Araşttrmaları Dergisi & RumeliDE Journal of Language and Literature Studies
\end{tabular} Osmanağa Mahallesi, Mürver Çiçeği Sokak, No:14/8 $\quad$ Osmanağa Mahallesi, Mürver Çiçeği Sokak, No:14/8 Kadıköy - ÍSTANBUL / TÜRKIYE 34714 Kadıköy - ISTANBUL / TURKEY 34714 e-posta: editor@rumelide.com e-mail: editor@rumelide.com, tel: +90 505 7958124, +90 2167730616 phone: +90 505 7958124, +90 2167730616
} 
The comparison of Türk Lügati dictionary with different types of dictionaries and an attempt on its arrangement / B. Sarıkaya (pp. 403-430)

yapılırken tamamen Arapça sözlüklerdeki kelimelerin açılamasının birebir tercümesi görülür. ${ }^{12}$ Buradaki iki madde başı derre ( دَّ), derre'e ve delle (دَّلَّ), delāleten örnekleri, eşadlı (homonim) ${ }^{13}$ sözlük özelliklerini uygulama isteğini çağrıştırmaktadır. Çünkü bu Arapça kelimeleri öğrenmek isteyen sözlük kullanıcısı bu sözlüğü kullanmayacaktır. Fakat Kadrî, bu kelimelerden müştak olan bütün bildiği kelimeleri Arapça çekimli fiillerin altında toplamıştır. TL'nin ve EŞ’nin madde başlarında yazılışı aynı olan kelimeleri, ister Türkçe ister Arapça olsun, alt alta getirmeleri eşyazımlı sözlük türünü hatırlatmaktadır.

\section{C.5. TL ile kökenbilgisi sözlüğü örneği EDT’nin sözlük birim bakımından karşılaştırılması}

Kökenbilgisi Sözlükleri bakımından Sir Gerard Clauson’un sözlüğünden balta kelimesini alalım: [Aşağıda birinci paragraf metnin orijinali, ikinci paragraf ise çevirisidir] (Clauson, 1972, s. 333).

"baltu: (balto:) 'an axe'; in the early period more specifically 'a battle axe', later more generally. S.i.a.m.l.g., in SE Türki paldu/ paltu Shaw, Jarring; palta BŞ; elsewhere balta. Uyğ. vıı ff. Man.A (then the god Hormuzd split the fiend's head) ot teyrig baltuça kılıp 'using the Fire God as an axe' M I 20, 13: Bud. Suv. 544, 6 (bedzet-): Xak. XI baldu: (sic) al-fa's 'axe' Kaş. 1 418; a.o. I11 421, 25: KB kayusı çerigde kılıç baldu yér 'some men suffer sword and axe (wounds) in the ranks' 1736; a.o. 2141: XIII(?) Tef. balta 'axe' 90: xıv Muh.(?) al-țabar 'axe' balta: Rif. 169 (only): Çă̆. xv ff. baltu balta tabar ma'nāsina Vel. 133 (quotn.); baltu tabar, in Ar. fa's San. 126v. 7 (same quotn.) : Oguz Xı otu:y kese:si: baldu: 'an axe ( $f a$ 's) for cutting firewood' Kaş. I 14, 2; n.m.e.: Xwar. XIV balta 'axe' Qutb 26: Kom. xıv 'small axe' balta CCI; Gr.: Kıp. xıv balța: 'an axe (al-fa's) used for chopping firewood' Id. 36: xv al-fa's balta: Kav. 64, 1; Tuh. 28a. 2."

baltu: (balto :) 'bir balta'; erken dönemde, daha spesifik olarak 'bir savaş baltası', daha sonra daha genel olarak. S.i.a.m.l.g., Güneydoğu Türki paldu / paltu Shaw, Jarring; palta BŞ; başka yerde balta. Uyğ. vıı ff. Man.-A (o zaman tanrı Hürmüzd şeytanın başını böldü) ot teyrig baltuça kılıp 'Ateş Tanrısını balta olarak kullanarak' M I 20, 13: Bud. Suv. 544, 6 (bedzet-): Xak. XI baldu: (sic) al-fa's 'baltası' Kaş. 1 418; a.o. I11 421, 25: KB kayusı çerigde kılıç baldu yér '1736 sıralarında bazı adamlar kılıç ve balta (yaralar) çekiyor'; a.o. 2141: XIII (?) Tef. balta 'balta' 90: xıv Müh. (?) el-abar 'balta' balta: Rif. 169 (yalnızca): Çă̆. xv ff. baltu balta tabar ma'nāsina Vel. 133 (alıntı); baltu tabar, Ar. fa's San. 126v. 7 (aynı alıntı): Oğuz xı otu: $\eta$ kese: si: baldu: 'yakacak odun kesmek için bir balta (fa's)' Kaş. I 14, 2; n.m.e.: Xwar. XIV balta 'balta' Kutub 26: Kom. xıv 'küçük balta' balta CCI; Gr .: Kıp. xıv balța: 'yakacak odun kesmek için kullanılan bir balta (al-fa's)' Id. 36: xv al-fa's balta: Kav. 64, 1; Tuh. 28a. 2.

Clauson, balta kelimesindeki; önce "bir savaş baltası" savaş için kullanılan alet, metinlerde kült özelliği kazanan öldürücü bir alet, son devirlerde ise odun kesmeye, yarmaya yarayan bir alet olarak anlam değişmelerini ele almıştır. Kelimenin de baltu, balto, paldu, paltu, baldu ve balta olmak üzere altı varyantı sunulmuştur. Acaba TL'de balta kelimesinden ne kadarlık bir etimolojik bir çalışma ürünü ortaya çıkarılabilir? balta, balța ve balto üç varyantı olan kelime, sadece odun kesmeye yarayan bir alet anlamı ile yer almaktadır. Belki ek alan kelimelerle birlikte ele alınırsa; baltacı "saray muhafizı", baltal/baltalu "yol açan askeri birlik, müsellem" ve baltalk "bir köye tahsis olunan orman" kelimelerinden bir katkı sağlanabilir.

İkinci olarak baldız kelimesine bir göz atalım: [Aşağıda birinci paragraf metnin orijinali, ikinci paragraf ise çevirisidir] (Clauson, 1972, s. 334).

“baldız 'a man's wife's younger sister'. Survives in this meaning in NW Kaz. and SW Az., Osm., Tkm., and also in NC Kir., Kzx. but according to MM 68 in Kzx. it also means 'younger sister' and even 'brother-in-law'. The last usage must be quite modern, but the use of the phr. eke baldız in Uyğ.

Kelimelerin yanındaki lugat, lazım ve müteaddi kelimeleri Arapça lügatten alınma olduğunu gösterdiği gibi süt çok olmak ve deve südüni akıtmak şeklinde açıklama Türkçe lügatlerde olmayan, Arapça cümle tercümesi olan bir açıklamadır.

Yazımları ayrı, söylenişleri aynı olan sesteşlere aynı zamanda homofon adı verilir: peace(barış) ve piece (parça) gibi. (Aksan, III: 193).

RumeliDE Dil ve Edebiyat Araştırmaları Dergisi Osmanağa Mahallesi, Mürver Çiçeği Sokak, No:14/8 Kadıköy - ÍSTANBUL / TÜRKIYE 34714 e-posta: editor@rumelide.com tel: +90 $5057958124,+902167730616$
Address

RumeliDE Journal of Language and Literature Studies

Osmanağa Mahallesi, Mürver Çiçeği Sokak, No:14/8

Kadıköy - ISTANBUL / TURKEY 34714

e-mail: editor@rumelide.com

phone: +90 505 7958124, +90 2167730616 
directly parallel to éçi ini suggcsts that it was also sometimes used in the sense of 'younger sister' even in Uyğ. Uyğ. viı ff. Bud. Suv. 554, 15- 16 (eke:): Xak. xı baldız uxtu'l-mar'ati'l-sugràa’a (man's) wife's younger sister'; a man's sister is called sinil, not baldız. Kaş. I 457; a.o. I11 7 (yurç): xı11(?) Tef. 72 (eke:), 90: xıv Muh.(?) uxtu'l-mar'a ba:Idu:z Rif. 144 (only).”

baldız 'bir erkeğin karısının küçük kız kardeşi'. Kuzeybatı Kaz'da bu anlamda hayatta kalır. ve SW Az., Osm., Tkm. ve ayrıca NC Kır., Kzx. ancak Kzx'de MM 68'e göre. aynı zamanda 'küçük kız kardeş' ve hatta 'kayınbirader' anlamına gelir. Son kullanım oldukça modern olmalı, ancak phr kullanımı. eke baldız uyğ. éçi ini'ye doğrudan paralel olarak, bazen Uyğ'da bile 'küçük kız kardeş' anlamında kullanıldığını öne sürüyor. Uyğ. vıı ff. Bud. Suv. 554, 15- 16 (eke:): Xak. xı baldız uxtu'l-mar'ati'l-şugrāa'a (erkek) karısının küçük kız kardeşi '; bir adamın kız kardeşine baldız değil sinil denir. Kaş. I 457; a.o. I11 7 (yurç): xulı (?) Tef. 72 (eke:), 90: xıv Muh. (?) Uxtu'l-mar'a ba:Idu:z Rif. 144 (yalnızca).

Clauson, baldız kelimesindeki bir erkeğin karısının küçük kız kardeşi, küçük kız kardeş, kayınbirader, (erkek) karısının küçük kız kardeşi, bir adamın kız kardeşine baldız değil sijil denir gibi bilinen ve kazandığı farklı anlamları baldız, ba:ldu:z, éçi ini, baldız, sinil, eke baldız gibi altı farklı şekli kullanarak anlatmıştır.

TL'de baldız kelimesi, lehçeler dikkate alınıp -Kazanca iki kez- beş kere madde başı yapılmıştır. Zevcenin küçük kız kardaşı, kayın simil, zevcenin kız kardaşı gibi üç anlamla baldyz, baldouz ve kayın simil olmak üzere üç farklı şekil ortaya konmuştur. Clauson, baldız kelimesini yakın anlamlı sinil, eke, eçi ini gibi kelimelerle karşılaştırarak açıklayıp, farklılıklara vurgu yapmıştır. Kadrî ise lehçeler arası aydınlatıcı ve karşılaştırmalı bilgi vermemiştir. Sadece Kazak lehçesi baldız madde başına bir örnek sunmuştur: Ağaç başı bazukdur, baldız alu yazukdur // Bazuk bolsa ni mina, yazuk kazuk başına Halk Sözlerinden (TL, I, s. 633) gibi.

Etimolojik sözlük hazırlanırken TL'den tanık bakımından faydalanılabilir, lehçe vurguları ve örnekler oldukça fazladır. Kelimelerin iştikakı hakkında bilgiler de içermektedir. Bu iştikak bilgileri daha çok kelimelerin görünen şekli ve türevleri hakkında olup, etimolojik sözlüğe doğrudan katkı sağlama amacı gütmemektedir. Etimolojik sözlük özelliklerine uzak kalan bu sözlük, bu tür sözlük çalışmasında pek iyi bir sonuç vermeyebilir.

\section{C.6. TL ile stilistik (sanatçı/lar ve metin/ler) sözlüklerinin sözlük birim bakımından karşılaştırılması}

$T L$ içindeki yazarların, görüşlerin veya akımların temsilcilerinin örnekleri ve örneklerindeki kavramların işlenmesiyle meydana getirilecek bir çalışma ortaya stilistik bir sözlük çıkarabilir mi? Tez olarak hazırlanan eserlerin tahlili ve tanzimi acaba bize hangi sonuçları verir? Son zamanlarda ortaya konan sözlük türü eserlerde örneklere oldukça fazla yer verilmektedir. Sözlüklerdeki örneklerle kelimelerin anlam ve muhteva farklılıkları daha belirgin hâle gelmektedir. Kubbealtı'nın hazırladığı Misalli Büyük Türkçe Sözlük ve Milli Eğitim Bakanlığının hazırlattığı Örnekleriyle Türkçe Sözlük bu tür sözlüklere örnek gösterilebilir. Bazı kişilerin veya eserlerin de sözlügü hazırlanmaktadır. Aksan, Ali Püsküllüoğlu'nun Yaşar Kemal Sözlüğünü Rezâzâde Şafak’ın Farhang-i Şahnâmesini ve Anayasa Sözlüğünü örnek gösterir (Aksan, III, s. 83). Niyâzînin Nevâyî'nin Sözleri ve Çağatayca Tamıklar (ElLugatu'n-Neva'iyye ve'l-İstişhadatu'l-Cagata'iyye) ile Türk dili alanındaki tezlerin çeviri yazılarından sonra hazırlanan bazı sözlükler de bu tür sözlüklere örnek olabilir. Mesela Günaydın, Ali Şir Nevâyînin Çağatay Türkçesi ile yazılmış dört divanını kapsayan doktora çalışmasında, sık sık referans yapılan âşsk, şeyh, sultân, mi'mâr, vâ'iz vb. yüz elli küsur divan edebiyatı tipini içeren bağlamsal, tanıklı ve açıklamalı bir sözlük hazırlamıştır (Günaydın, 2017, s. III). Yakın ve karşıt anlamlı kelimelerin göndermelerle

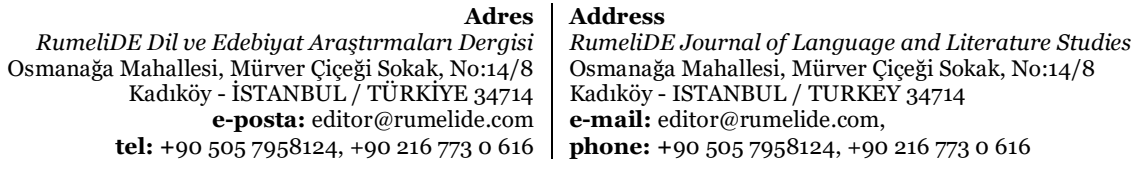


birbirine yönlendirildiği bu stilistik sözlük örneğinde olduğu gibi, TL'deki belli kavramlar, kelimeler ve deyimler altında tanık olan Fuzûlî, Nedîm, Mehmet Akif vb. şairlerin şiirleri, sanatçı sözlüğü veya ortak sanat akımları sözlüğü gibi stilistik sözlük örneğinin tanıkları olabilir.

\section{Sonuç}

Osmanlı dönemi sözlüklerinden biri olan ve çokça tenkide maruz kalan Türk Lügati henüz tamamıyla sözlük kullanıcılarının hizmetine sunulmamıştır. Sözlükbilimi alanında adı devamlı geçen bu eserin tenkitli basımı hâlâ yapılmamıştır. Arkadaşlarıyla Türk Lügatini yazmaya başlayan ve sonra yalnız başına yoluna devam etmak zorunda kalan Hüseyin Kazım Kadrî, sözlükbilimci olmadığı ve kanaatimce topladığı verileri de işleyecek zaman bulamadığı için kusurlu bir sözlük ortaya koymuştur. Son zamanlarda divan edebiyatı araştırmacıları, sözlükten veri tabanı bazlı faydalanarak tezler hazırlamışlardır. Bu tezlerin bazıları kelimelerin ve örneklerinin açıklanması tarzında, bazıları ise edebiyat terimlerinin açıklamaları ve örneklendirmeleri bağlamında olmuştur. Tez çalışmalarında daha çok metnin tamiri üzerinde yoğunlaşıldığı görülmektedir. Sözlükbilimi alanında ise bu sözlükle ilgili pek az çalışma yapılmıştır. Türk Lügati genel sözlük, lehçeler sözlüğü, tarihi sözlük, deyimler ve atasözleri sözlüğü, sanatçı/metin sözlüğü çalışmalarında kullanılabilecek birçok veriyi içermektedir. Farklı türdeki sözlük kaynaklarına pek çok tanık aktarabilecek kapasiteye sahip olan bu eser, sözlükbilimi geleneğine uygun olarak hazırlanmalı, sözlük kullanıcılarına dijital ortamda sunulmalıdır.

Çalışmada yapılan karşılaştırmalarda sözlükle ilgili kuramsal görüşlerin uygulanması yönünde bazı pratiklere ulaşılmış, sözlüğün sözlükbilimi alanında daha kullanışlı hâle getirilmesinin mümkün olduğu sonucuna varılmıştır. Türk Lügatinin tenkitli basımında yapılabilecek çalışmalar; tekrarların kaldırılması, madde başı kelimelerin sıralanması/tertibi ve müstakil çalışmalar olarak üç bölümde şöyle özetlenebilir:

1. Madde başları ve iç maddeler tekrarlardan kurtarılmalıdır. Bazı kelimelerin türü ve dili ile ilgili aynı bilgiler bir sayfada defalarca yer almaktadır. Tekrarlardan kurtulan eserin de hacmi, makul seviyeye çekilmiş olacaktır. Bir kelimenin varyantlarının ve bilgilerinin tarihsel veya etimolojik sözlüklerdeki gibi bir araya getirilmesi, sözlüğü çok yazı, az bilgi sarmalından kurtaracaktır. Farklı lehçelere bağlı olarak çoğaltılan madde başlarının varyantları lehçe bilgilerini koruyacak farklı işaretlerin yardımıyla bir araya getirilmelidir. Böylece kelimelerin lehçe bakımından karşılaştırılmaları kolaylaşacaktır.

2. Kendinden evvelki kelimelerle eş yazımlı olan Arapça kelimelerin Türkçede kullanılmayan ama Arapça sözlüklerde bulunan çekimli şekillerinin madde başı yapılması, iştikaki sözlük anlayışının sözlükte tezahürü olarak Türkçede kullanılan Arapça kökenli kelimelerin Arapça mastarlarının alt maddesi yapılması ve her kelimenin alt maddesi olan kelime, kelime grubu veya cümlenin; darb-1 meseller, özel anlam kazanan kelime grupları, kendi anlamını koruduğu kelime grupları, deyimler ve türemiş kelimeler şeklinde sıralanması alfabetik dizgiye aykırı düşmektedir. Bu farklılıkları giderecek şekilde düzenleme yapılmalıdır.

3. Türk lehçelerinde bulunan deyimler ve atasözleri konusunda veya sözlüğün belli bölümlerinin lehçebilim, etimolojik, stilistik vb. sözlük özellikleri çerçevesinde çeviri yazıya aktarımı gibi birçok bağımsız çalışma ortaya konabilir.

Büyük bir veri tabanı hazırlayan Kadrî̀yi minnetle anarken, sözlük türlerinin birçok örneğini tanıma ve inceleme şansına kavuşan sözlükbilimcilerin Kadrînin gayretli çalışmasıyla ortaya çıkan eserini dağınık

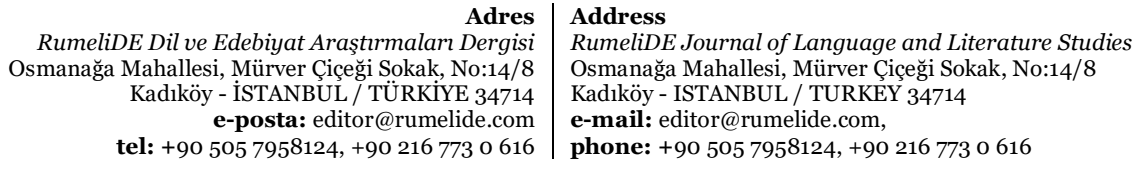


görüp tenkit etmesini de tabi görmek gerekir. Türk birliğine katkı sunmak isteyen Kadrî ile aynı duygu ve düşünceleri paylaşanlar, Türk Lügatini Ercilasun'un de açıkladığı gibi sözlükbilimi kurallarına (Ercilasun, 1999, s. 80) göre lehçebilim sözlüğü türünde düzenlemeli, eseri kolay kullanılabilir hâle getirmelidirler. Bu çalışmaları yapacak sözlükbilimciler, hem Kadrînnin arkadaşları Fikret’in ve Hüseyin Cahit'in görevini yapmış olacak hem de Çağdaş Türk Lehçelerinde sözcükbilimin ve sözlükbiliminin tarihi seyrine katkı sunacak değerli bir eseri bilim âlemine kazandırmış olacaktır. Günümüzde Çağdaş Türk Lehçeleri ile ilgili modern çalışmaların ve hazırlanan sözlüklerin öncülerinin bu gibi eserler olduğu unutulmamalıdir.

\section{Kisaltmalar}

$\begin{array}{ll}\text { bk. } & \text { bakını } \\ E S ̧ & \text { Eser-i Şevket } \\ K T & \text { Kâmûs-i Türkî } \\ D S & \text { Derleme Sözlüğü } \\ \text { KTLS } & \text { Karşlaşttrmalı Türk Lehçeleri Sözlüğü } \\ \mathrm{s.} & \text { sayfa } \\ T D E S & \text { Türk Dilinin Etimolojik Sözlüğü } \\ T D K & \text { Türk Dil Kurumu } \\ T L & \text { Türk Lügati } \\ \text { TT } & \text { Türkiye Türkçesi } \\ \text { vb. } & \text { ve benzeri }\end{array}$

\section{Kaynakça}

Aksan, D. (2009). Her Yönüyle Dil, Ana Çizgileriyle Dilbilim. Ankara: TDK.

Aksoy, Ömer A. (1993) Atasözleri ve Deyimler Sözlüğü, C. I, 7. baskı. İstanbul: İnkılap.

Aksoy, Ömer A. (1989) Atasözleri ve Deyimler Sözlüğü, C. II, 5. baskı. İstanbul: İnkılap.

Ateş, M. (2017). Eser-i Şevket Transkripsiyonlu Metin İnceleme [452 s. - 572 s.] Erzincan Üniversitesi Sosyal Bilimler Enstitüsü.

Clauson, Sir G. (1972). An Etymological Dictionary of Pre-Thirteenth Century Turkish, Oxford: Oxford University Press.

Devellioğlu, F. (1988). Osmanlıca-Türkçe Ansiklopedik Lügat, Ankara: Aydın.

Ercilasun, A. B. (1992). Karşılaştırmalı Türk Lehçeleri Sözlüğü I-II. Ankara: Kültür Bakanlığı.

Ercilasun, A. B. (1999). Karşılaştırmalı Türk Lehçeleri Sözlüğü Üzerine: Uluslar Arası Sözlük Bilimi Sempozyumu Gazimagosa. [Demir N. ve Yılmaz E. (tarihsiz). Uluslar Arası Sözlük Bilimi Sempozyumu Bildirileri, 2. baskı. Ankara: Hacettepe Yayıncllık. 77-81'dan alınmıştır.]

Eren, H. (1999). Türk Dilinin Etimolojik Sözlüğü, 2. baskı. Ankara: Bizim Büro Basım evi.

Görel, Ö. (2019). Türk Lügati'nde "Dal" maddesi (Metin-dizinler-sözlük). Afyon Kocatepe Üniversitesi / Sosyal Bilimler Enstitüsü / Türk Dili ve Edebiyatı Anabilim Dalı.

Günaydın, A. (2017). Ali Şir Nevâŷ̂’nin Dîvânlarında İnsan Görünümleri. İstanbul Üniversitesi, Sosyal Bilimler Enstitüsü, Türkiyat Araştırmaları Anabilim Dalı.

Hüseyin Kazım Kadrî. (1927). Türk Lügati, Türk Dillerinin İştikakı ve Edebi Lügatleri, I. İstanbul: Devlet Matbaasi.

Kaçalin, M. S. (2011). Niyâzî Nevâyî'nin Sözleri ve Çağatayca Tanıklar (El-Lugatu'n-Neva’iyye ve‘lİstişhadatu'l-Cagata'iyye). Ankara: Türk Dil Kurumu.

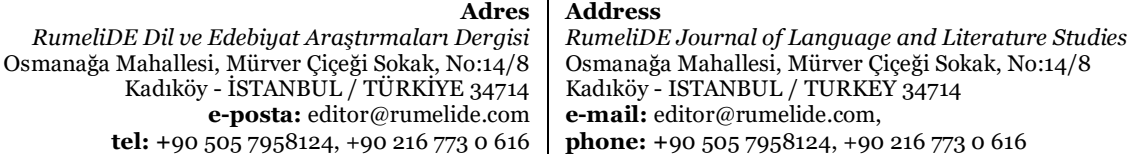


Menınskı, Franciscus à Mesgnien, Thesaurus Linguarum Orientalium Turcicae-Arabicae-Persicae, Simurg Yay., İstanbul 2000.

Mütercim Asım Efendi. (2009). Burhan-ı Katı. (Hazırlayanlar: Mürsel Öztürk \& Derya Örs). Ankara: TDK.

Öbek, A. İ. (2009). Tarihî Türk Sözlükçülüğünde Dönüm Noktası: [Büyük] Türk Lügatı. Journal of Turkish Studies.

Somuncu, M. (2020). “Ötüken Türkçe Sözlük ün Sözlükbilimi Yöntemlerine Göre İncelenmesi, Kesit Akademi Dergisi, 6 (24): 204-223. http://dx.doi.org/10.29228/kesit.44871

Şemseddîn Sâmî (2015). Kâmûs-i Türkî. İstanbul: Çağrı Yayınları. [Dersaadet: İkdam Matbaası. 1317]

Yavuzaslan, P. (2009). Osmanlı Dönemi Türk Sözlükçülüğü. Ankara: Tiydem.

RumeliDE Dil ve Edebiyat Araştırmaları Dergisi Osmanağa Mahallesi, Mürver Çiçeği Sokak, No:14/8 Kadıköy - İSTANBUL / TÜRKIYE 34714 e-posta: editor@rumelide.com tel: +90 $5057958124,+902167730616$
Address

RumeliDE Journal of Language and Literature Studies Osmanağa Mahallesi, Mürver Çiçeği Sokak, No:14/8

Kadıköy - ISTANBUL / TURKEY 34714

e-mail: editor@rumelide.com

phone: +90 $5057958124,+902167730616$ 